\title{
Occurrence, Evolution and Specificities of Iron-Sulfur Proteins and Maturation Factors in Chloroplasts from Algae
}

\author{
Jonathan Przybyla-Toscano ${ }^{1}\left(\mathbb{D}\right.$, Jérémy Couturier ${ }^{1}\left(\mathbb{D}\right.$, Claire Remacle $^{2, *}$ and Nicolas Rouhier ${ }^{1, *}(\mathbb{C})$ \\ 1 Université de Lorraine, INRAE, IAM, F-54000 Nancy, France; \\ jonathan.przybyla-toscano@univ-lorraine.fr (J.P.-T.); jeremy.couturier@univ-lorraine.fr (J.C.) \\ 2 Genetics and Physiology of Microalgae, InBios/Phytosystems Research Unit, University of Liège, \\ 4000 Liège, Belgium \\ * Correspondence: c.remacle@uliege.be (C.R.); nicolas.rouhier@univ-lorraine.fr (N.R.); \\ Tel.: +32-43-663-812 (C.R.); +33-372-745-157 (N.R.)
}

Citation: Przybyla-Toscano, J.;

Couturier, J.; Remacle, C.; Rouhier, N.

Occurrence, Evolution and

Specificities of Iron-Sulfur Proteins and Maturation Factors in

Chloroplasts from Algae. Int. J. Mol.

Sci. 2021, 22, 3175. https://doi.org/

$10.3390 /$ ijms 22063175

Academic Editor: Se-Kwon Kim

Received: 10 January 2021

Accepted: 17 March 2021

Published: 20 March 2021

Publisher's Note: MDPI stays neutral with regard to jurisdictional claims in published maps and institutional affiliations.

Copyright: (C) 2021 by the authors Licensee MDPI, Basel, Switzerland. This article is an open access article distributed under the terms and conditions of the Creative Commons Attribution (CC BY) license (https:// creativecommons.org/licenses/by/ $4.0 /)$

\begin{abstract}
Iron-containing proteins, including iron-sulfur (Fe-S) proteins, are essential for numerous electron transfer and metabolic reactions. They are present in most subcellular compartments. In plastids, in addition to sustaining the linear and cyclic photosynthetic electron transfer chains, Fe-S proteins participate in carbon, nitrogen, and sulfur assimilation, tetrapyrrole and isoprenoid metabolism, and lipoic acid and thiamine synthesis. The synthesis of Fe-S clusters, their trafficking, and their insertion into chloroplastic proteins necessitate the so-called sulfur mobilization (SUF) protein machinery. In the first part, we describe the molecular mechanisms that allow Fe-S cluster synthesis and insertion into acceptor proteins by the SUF machinery and analyze the occurrence of the SUF components in microalgae, focusing in particular on the green alga Chlamydomonas reinhardtii. In the second part, we describe chloroplastic Fe-S protein-dependent pathways that are specific to Chlamydomonas or for which Chlamydomonas presents specificities compared to terrestrial plants, putting notable emphasis on the contribution of Fe-S proteins to chlorophyll synthesis in the dark and to the fermentative metabolism. The occurrence and evolutionary conservation of these enzymes and pathways have been analyzed in all supergroups of microalgae performing oxygenic photosynthesis.
\end{abstract}

Keywords: maturation; iron-sulfur proteins; chloroplasts; microalgae; fermentation

\section{Introduction}

Iron $(\mathrm{Fe})$ is a highly abundant metal on earth, and was present at the origin of life in ferrous form $\left(\mathrm{Fe}^{2+}\right)$ associated with sulfur in pyrite $\left(\mathrm{FeS}_{2}\right)$, as well as contributing to electron transfer reactions. In the oxygenic atmosphere encountered nowadays, Fe is more accumulated in the poorly bioavailable oxidized $\mathrm{Fe}^{3+}$ form. However, $\mathrm{Fe}$ is essential in modern organisms and is necessary in substantial amounts, due to its presence in protein cofactors, i.e., iron-sulfur (Fe-S) clusters, hemes, and non-heme non-Fe-S mono- or di-iron cofactors [1]. Current estimates indicate that 2 to $10 \%$ of the proteomes of archaea, bacteria and eukarya are Fe-dependent proteins, representing, for instance, more than 1000 proteins in Arabidopsis thaliana (Arabidopsis) (approximately 4\% of the proteome) [1]. Around 200 putative Fe-S proteins have been counted in Arabidopsis, the vast majority containing the most frequent rhombic (2Fe-2S) and cubane (4Fe-4S) cluster types as compared to the intermediate ( $3 \mathrm{Fe}-4 \mathrm{~S}$ ) cluster forms. More complex and atypical Fe-S clusters are observed in nature, mainly in proteins (e.g., nitrogenases, hydrogenases (HYDs), hybrid cluster proteins (HCPs)) present in prokaryotes and in some primitive eukaryotes including microalgae [2]. All these diverse Fe-S cluster forms confer to the associated proteins a wide range of functions, such as electron, sulfur or iron atom donors, intracellular oxygen or Fe concentration sensors, or else as Lewis acid catalysts, to cite a few examples [3]. As for mitochondria [4], the chloroplast has a very high demand in Fe-S cofactors, notably in the photosynthetic electron transport chain [5]. They are present in complexes involved in the 
linear electron transfer chain, including one (2Fe-2S) cluster in the Rieske subunit of the cytochrome $\mathrm{b}_{6} \mathrm{f}$, three $(4 \mathrm{Fe}-4 \mathrm{~S})$ clusters in photosystem I (PSI) subunits, and one (2Fe-2S) cluster in the final electron acceptor ferredoxin (FDX) [6]. They are also required for the cyclic electron transfer chain, since (4Fe-4S) clusters are bound by the plastid-encoded NDH-K and NDH-I subunits of the chloroplastic NADH dehydrogenase (NDH) complex, and an Fe-S cluster of unknown nature is also likely bound to PGR5-like photosynthetic phenotype 1 (PGRL1), an actor of the second pathway supporting cyclic electron transport [7-9]. In addition, stromal or thylakoid-bound Fe-S proteins participate in carbon, nitrogen, and sulfur assimilation, tetrapyrrole and isoprenoid metabolism, and ensure the biosynthesis of cofactors (i.e., lipoic acid and vitamin B1/thiamine) [5]. The de novo Fe-S cluster assembly, trafficking and insertion into chloroplastic proteins necessitate a protein machinery formed by ca. 15 proteins in terrestrial plants, namely the sulfur mobilization (SUF) machinery $[5,10]$. This machinery is also present in archaea and some bacteria, including Escherichia coli $[11,12]$. In the green lineage, previous studies of the SUF machinery have essentially been performed using cyanobacteria and Arabidopsis and to a much lesser extent with Chlamydomonas reinhardtii (Chlamydomonas) $[5,13,14]$. Hence, in the second section, after describing the current model for the molecular mechanisms used by the SUF machinery that sustain Fe-S cluster synthesis and insertion into acceptor proteins, we analyze the occurrence of the SUF components in Chlamydomonas, but also in the supergroups of microalgae. In the third section, we focused on the chloroplastic Fe-S protein-dependent pathways that are specific to Chlamydomonas, or for which Chlamydomonas presents specificities compared to terrestrial plants.

\section{Maturation of Iron-Sulfur Proteins by the SUF Machinery}

\subsection{Lessons from Escherichia coli and Arabidopsis thaliana}

From its presence in archaeal genomes and prevalence in (facultative) anaerobe bacteria, the SUF system is considered to be the most ancient Fe-S cluster biogenesis pathway, present even in early anaerobic forms of life [12,15]. Life in aerobiosis apparently led to its complexification, notably adding the SufA/D/E/S genes to the "ancestral" SufB/C genes as it now exists in the E. coli SUF operon (SufABCDSE) [12]. In this model bacterium, the SUF machinery operates under stress and Fe starvation conditions when the housekeeping ISC (iron-sulfur cluster) machinery is no longer operative [11,16]. However, in some other bacteria, the SUF system is the sole or major Fe-S biogenesis system, with some genes such as SufD sometimes being absent, or new ones such as SufU or SufT having appeared [15]. During evolution, photosynthetic eukaryotes have inherited the SUF system from cyanobacteria for the maturation of chloroplastic/plastidial Fe-S proteins, but innovations have appeared throughout evolution, notably in the green lineage. The SUF components have mostly been studied in E. coli and Arabidopsis by combining genetic analyses with biochemical and structural approaches. This led to the proposition of some unifying mechanistic concepts for Fe-S protein biogenesis by the SUF machinery $[5,11,17]$. Schematically, this process can be divided into two chronological steps involving (i) de novo Fe-S cluster synthesis on scaffold proteins and (ii) the conversion, trafficking, and insertion into acceptor proteins using Fe-S cluster transfer proteins (Figure 1). 


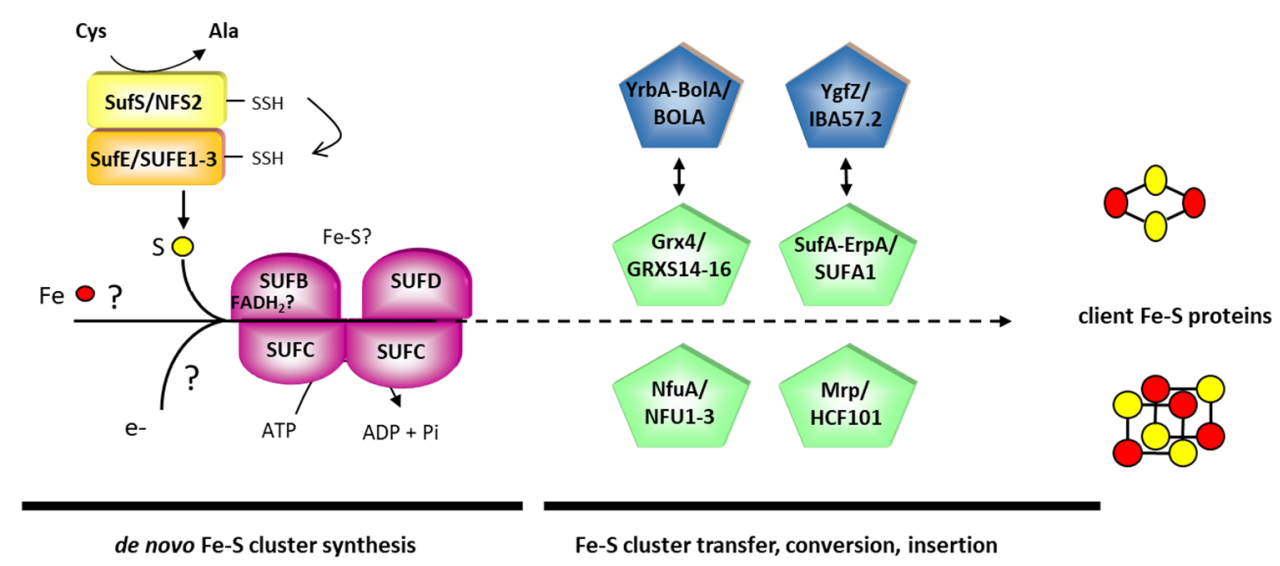

Figure 1. Working model of the SUF system. Both the E. coli and A. thaliana protein nomenclatures are indicated in this order unless they are similar. The sulfur (S) delivery system is shown in yellow/orange, the iron-sulfur (Fe-S) cluster scaffold complex in violet, the Fe-S cluster transfer proteins in green and associated targeting factors in blue. So far, it is believed that NFU and HCF101 are mostly responsible for the maturation of (4Fe-4S)-containing client proteins, and GRX and SUFA for the maturation of (2Fe-2S)-containing client proteins. Other details are found in the text and are not repeated here for the sake of concision.

For de novo Fe-S cluster synthesis, a class II pyridoxal 5'-phosphate (PLP)-dependent cysteine desulfurase (CD), SufS and CsdA in E. coli, or NFS2 in A. thaliana catalyzes the desulfuration of cysteine, leading to the formation of a persulfide group on a catalytic cysteine [17]. The class II CDs usually require the SufE/CsdE or SUFE sulfur shuttle proteins to enhance their activity [18-20]. In some organisms such as the $\mathrm{Gram}^{+}$bacterium Bacillus subtilis, this role is played by SufU [21]. SufE proteins also possess an ultra-conserved cysteine residue, which receives the persulfide from SufS/NFS2. The interaction between these SufS and SufE leads to a slight conformational change that facilitates the desulfuration reaction, thus explaining the enhancement of the cysteine desulfurase activity [22]. Using E. coli proteins, it has been shown that the persulfide intermediate is then transferred to the SufB present in a SufBC ${ }_{2} \mathrm{D}$ scaffold complex (1:2:1 stoichiometry), in which the ABC-type ATPase SufC catalyzes ATP hydrolysis, and SufB and D subunits are thought to bind the Fe-S cluster, even though both the type of Fe-S cluster and its ligands are as yet unknown [23-25]. In vitro assays have shown that a (2Fe-2S) or a (4Fe-4S) cluster can be assembled in SufB alone or in complex with SufC and SufD $[23,26,27]$. From SufS to $\mathrm{SufBC}_{2} \mathrm{D}$, sulfur atom(s) are carried as persulfides (0 oxidation state). However, in Fe-S clusters, they are present as sulfide ions ( -2 oxidation state). Thereby, electrons are required to reduce sulfane sulfur $\left(\mathrm{S}^{0}\right)$ atoms. It may also be that electrons are required for the reduction of $\mathrm{Fe}^{3+}$ to $\mathrm{Fe}^{2+}$ or for the reductive coupling of two (2Fe-2S) clusters into one ( $4 \mathrm{Fe}-4 \mathrm{~S})$ cluster on SufBCD if the binding of both cluster types turns out to be physiological. The origin of these electrons is unknown, but it has been proposed that $\mathrm{FADH}_{2}$, which was associated with the E. coli $\mathrm{SufBC}_{2} \mathrm{D}$ complex when purified under anaerobic conditions, and/or the NADPH-dependent thioredoxin system may have a role at this step [26,28,29]. In the mitochondrial assembly complex, frataxin has been shown to stimulate persulfide transfer from the NFS1 cysteine desulfurase to the ISCU scaffold, as shown for mammalian proteins $[30,31]$. From the observation that frataxin is able to interact with the Bacillus subtilis SufU-SufS couple [32] and may be present in chloroplasts [33], an involvement in the chloroplastic SUF machinery is suggested. However, in the absence of experimental evidence to firmly associate frataxin with the SUF assembly system, and considering that the composition and structures of the ISC and SUF assembly systems are completely different, such a role so far remains highly uncertain. Finally, how Fe is delivered to the assembly complex and how Fe entry is controlled and coordinated is as yet completely unclear.

Once the newly formed (2Fe-2S) or (4Fe-4S) cluster is assembled on the SUF scaffold system, it has to be delivered to specific acceptor proteins (Figure 1). This step is obviously 
crucial for generating functional chloroplastic Fe-S proteins and requires Fe-S cluster transfer proteins belonging to the A-type carrier (ATC), IBA57, glutaredoxin (GRX), BOLA, NFU and multiple resistance and $\mathrm{pH}$ adaptation (MRP) families. In E. coli or $A$. thaliana, the proteins are respectively referred to as SufA-ErpA/SUFA1, YgfZ/IBA57.2, Grx4/GRXS1416, BolA-YrbA/BOLA1-4, NfuA/NFU1-3 and Mrp/high chlorophyll fluorescence 101 (HCF101). Unlike GRX, SUFA, NFU and HCF101 proteins, the BOLA and IBA57 proteins do not bind any Fe-S clusters themselves. For this reason, BOLA and IBA57 proteins are sometimes referred to as targeting factors and are rather hypothesized to mediate the interaction with or to recruit client Fe-S proteins. However, GRX and BOLA form Fe-S cluster-bridged heterodimers, as notably shown for the Arabidopsis GRXS14-BOLA1 couple [34]. Still, the precise role and hierarchical organization of all these late-acting factors as well as the molecular details involved at this step are far from being understood. The most intensive studies concerning the potential roles and targets of these proteins have been performed for the cases of E. coli SufA and NfuA $[35,36]$ and of $A$. thaliana NFUs. In Arabidopsis, with the exception of the essential HCF101 protein [37], the other proteins characterized so far, including NFU1-3, are dispensable [38-40]. While the viability of Arabidopsis mutants has helped to study the role of most late-acting factors, this suggests a certain functional redundancy between these protein families and/or the coexistence of parallel pathways that are difficult to characterize. Using Arabidopsis mutant analyses coupled to proteomic, protein-protein interaction and in vitro Fe-S cluster transfer studies, the current model for NFU proteins is that NFU1 is dispensable for growth under standard conditions, possibly acting as a back-up system for NFU2 and NFU3 in specific conditions or for the maturation of some specific client proteins. From the lethality of a double $n f u 2$ $n f u 3$ mutant, it seems that NFU2 and NFU3 act redundantly for some essential proteins, alimenting in particular HCF101 for the maturation of the PSI subunits, PsaA-C, which require (4Fe-4S) clusters [40-42]. According to the capacity of the recombinant protein to bind either a (2Fe-2S) cluster or a (4Fe-4S) cluster [43], NFU2 additionally serves for the maturation of a dihydroxyacid dehydratase, a (2Fe-2S)-containing enzyme involved in the synthesis of branched chain amino acids [40,44]. The precise roles of other Fe-S cluster transfer proteins remain to be delineated in the future, even though GRXS14 and SUFA1 were shown to be competent Fe-S cluster donors for FDXs in vitro $[38,45,46]$ and GRXS14 shown to transfer an Fe-S cluster to SUFA1 [47].

\subsection{Occurrence of the SUF Components in Microalgae}

Microalgae are a phylogenetically diverse group of eukaryotic photosynthetic microorganisms that thrive in various environments. Notably, the phylogenetic classification is still not well established, and it may differ slightly depending on the source. It is accepted that microalgae are split into several supergroups of the tree of life [48,49], which are not exclusively photosynthetic except for the Archaeplastids. The Archaeplastids are defined by the presence of a primary plastid derived from a cyanobacterium, and comprise, in particular, the Glaucophytes, the red algae (Rhodophytes), the green algae (Chlorophytes) and the Streptophytes, where the land plants and their closest algal relatives are found. The other microalgae possess secondary plastids derived from green or red algae and are spread among other supergroups. The Heterokonts include the well-known diatoms such as Phaeodactylum tricornutum. The Alveolates comprise the genus Symbiodinium, in which many species form symbiotic association with corals and the Chromerida phylum including Vitrella brassicaformis and Chromera velia, two photosynthetic relatives of Apicomplexes [50]. The Rhizaria comprise amoeboid protists of which some are photosynthetic (Bigelowiella natans). The Haptophytes comprise the marine species Emiliania huxleyi, which can grow at high density and can be responsible for algal blooms. The Cryptophytes comprise the marine species Guillardia theta. The Excavates contain photosynthetic Euglenids such as the freshwater microalga Euglena gracilis.

A previous genomic analysis identified known SUF components in C. reinhardtii [51]. However, new factors are now proposed to be part of the SUF machinery in eukaryote 
photosynthetic organisms and other microalgal genomes were not investigated. The recent Phycocosm sequencing project offers a unique opportunity to compare how the SUF system evolved in microalgae with very diverse origins and to determine whether adaptations occurred during evolution [49]. Using Chlamydomonas SUF proteins as references (Table 1), we performed a comparative genomic analysis of 25 organisms representing microalga diversity (Table 2).

Table 1. SUF components in C. reinhardtii. The sequences of SUF components present in C. reinhardtii were retrieved from the currently available genome version (v5.5) found in phytozome using a blast search performed with Arabidopsis sequences. A manual curation was necessary for some gene/protein sequences (GRX3, BOL1 and newly named NFU1). Based on genomic sequence analysis, a gene model was proposed for SUFA1 $\left({ }^{*} \mathrm{Cre} 06 \mathrm{~g} 299350\right.$ in the coming v6 genome release), which has thus far been absent. Finally, a change in the NFU nomenclature was asked to fit with the names in Arabidopsis and the phylogenetic analysis performed in [40]. The current NFU3 gene model (Cre17.g710800) will be renamed NFU1, whereas the current NFU1 (Cre18.g748447) will be renamed NFU2. All these changes are already integrated here and will be visible in the next genome release.

\begin{tabular}{|c|c|c|c|}
\hline $\begin{array}{l}\text { Chlamydomonas Gene } \\
\text { Names }\end{array}$ & $\begin{array}{l}\text { Accession } \\
\text { Numbers }\end{array}$ & Function(s) & Arabidopsis Orthologs \\
\hline CSD4, SUFS1 & Cre12.g525650 & \multirow[t]{2}{*}{$\begin{array}{l}\text { Cysteine desulfurase, sulfur } \\
\text { donor }\end{array}$} & At1g08490 (NFS2) \\
\hline CSD2, NIFS2 & Cre07.g322000 & & None \\
\hline \multirow[t]{2}{*}{ SUFE1 } & \multirow[t]{2}{*}{ Cre06.g309717 } & \multirow[t]{2}{*}{$\begin{array}{l}\text { Sulfur relay system from } \\
\text { cysteine desulfurase }\end{array}$} & At4g26500 (SUFE1) \\
\hline & & & $\begin{array}{l}\text { At1g67810 (SUFE2) } \\
\text { At5g50210 (SUFE3) }\end{array}$ \\
\hline SUFB & Cre15.g643600 & Scaffold protein complex & At4g04770 (SUFB) \\
\hline SUFC & Cre07.g339700 & Scaffold protein complex & At3g10670 (SUFC) \\
\hline SUFD & Cre12.g513950 & Scaffold protein complex & At1g32500 (SUFD) \\
\hline GRX3 & Cre07.g325743 & \multirow[t]{2}{*}{$\begin{array}{l}\text { Transfer protein, involved in } \\
\text { Fe-S cluster trafficking }\end{array}$} & At3g54900 (GRXS14) \\
\hline GRX6 & Cre01.g047800 & & At2g38270 (GRXS16) \\
\hline$B O L 1$ & Cre03.g180700 & \multirow[t]{2}{*}{$\begin{array}{l}\text { Targeting factor, involved in } \\
\text { Fe-S cluster trafficking }\end{array}$} & At1g55805 (BOLA1) \\
\hline BOL4 & Cre09.g394701 & & At5g17560 (BOLA4) \\
\hline SUFA1 & Cre06g299350* & $\begin{array}{l}\text { Transfer protein, involved in } \\
\text { Fe-S cluster trafficking }\end{array}$ & At1g10500 (SUFA1) \\
\hline IBA57.2/CGL77 & Cre12.g552850 & $\begin{array}{l}\text { Targeting factor, involved in } \\
\text { Fe-S cluster trafficking }\end{array}$ & At1g60990 (IBA57.2) \\
\hline NFU1 & Cre17.g710800 & \multirow[t]{2}{*}{$\begin{array}{l}\text { Transfer protein, involved in } \\
\text { Fe-S cluster trafficking }\end{array}$} & At4g01940 (NFU1) \\
\hline NFU2 & Cre18.g748447 & & $\begin{array}{l}\text { At5g49940 (NFU2) } \\
\text { At4g25910 (NFU3) }\end{array}$ \\
\hline HCF101 & Cre01.g045902 & $\begin{array}{l}\text { Transfer protein, involved in } \\
\text { Fe-S cluster trafficking }\end{array}$ & At3g24430 (HCF101) \\
\hline
\end{tabular}




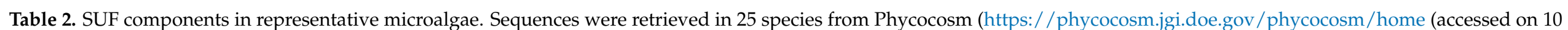

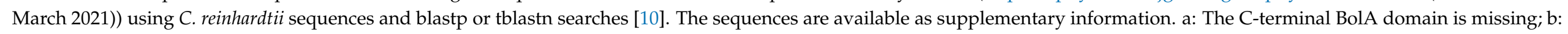

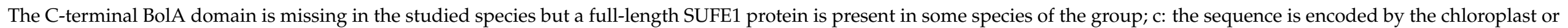

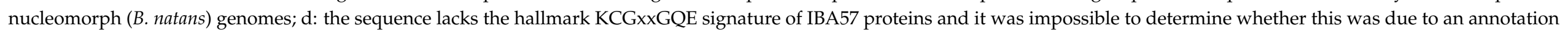

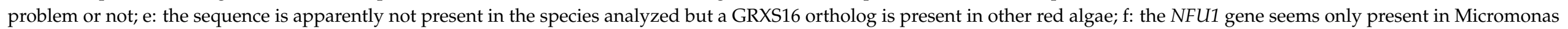

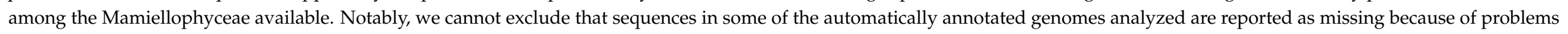
in the genome assembly.

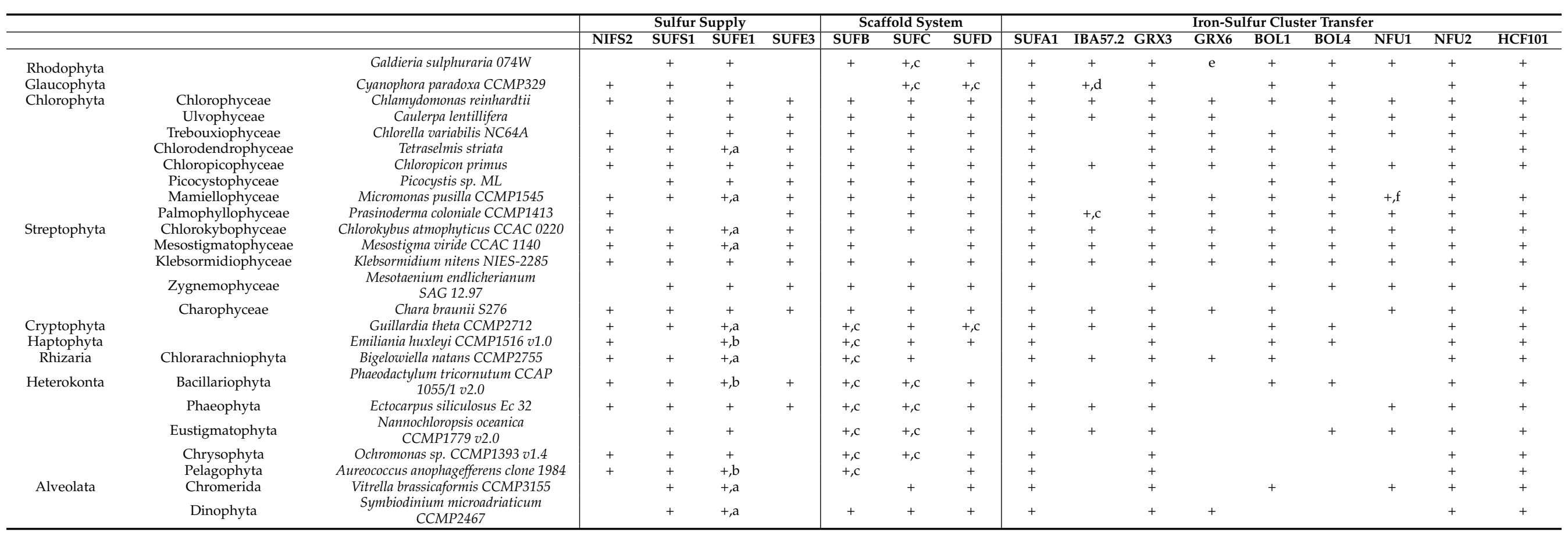


Chlamydomonas seems to have an expanded $\mathrm{CD}$ family with five putative sequences (CSD1, 2, 4, 5 and ABA3), where Arabidopsis has, for instance three members (NFS1, NFS2 and ABA3). Two isoforms are likely present in chloroplasts. The so-called Chlamydomonas SUFS1/CSD4 was detected in a chloroplast proteomic study and is in fact the ortholog of Arabidopsis NFS2 and E. coli SufS [52]. With few exceptions, it is present in all algal genomes analyzed (Table 2), but also in cyanobacteria. The second CD putatively expressed in chloroplasts based on subcellular localization predictions and on the presence of a characteristic N-terminal extension is referred to as NIFS2/CSD2. In this case, we found no supportive proteomic evidence. Similar sequences possessing an $\mathrm{N}$-terminal extension are present in numerous algal groups, but not all (Table 2). Noticeably, this isoform is present in organisms apparently lacking SUFS1. Orthologs are present in many bacteria, but not in terrestrial plants (bryophytes, lycophytes, angiosperms), suggesting that the gene was lost after the divergence between charophytes and terrestrial plants. In current models, class II CDs are associated with a sulfur relay protein, either SufU or SufE. Only SUFE proteins are present in eukaryote photosynthetic organisms. Dicotyledonous plants, such as A. thaliana, typically contain three proteins with SufE domains [10], while a single SUFE protein is present in cyanobacteria. From the amino acid sequence and phylogenetic analyses, the $A$. thaliana SUFE1 likely corresponds to the ancestral SUFE protein found in cyanobacteria, to which a BolA domain has been added in the C-terminal part. All microalgae analyzed possess the SUFE1 prototype. However, the BolA domain is sometimes absent in microalgal sequences whereas it is systematically present in proteins from terrestrial plants. The evolutionary scenario is difficult to retrace but this suggests that the BolA domain is dispensable in some organisms but may have become indispensable in terrestrial plants for the SUFE1 function because there is no example of SUFE1 proteins devoid of BolA domain in these organisms. The SUFE2 protein is formed by a single SufE domain. This gene likely appeared after the divergence between charophytes and terrestrial plants since it is absent in all microalgae. In fact, it may have specialized functions in terrestrial plants, since it is specifically expressed in reproductive organs [53]. The SUFE3 prototype is formed by a SufE domain fused to a quinolinate synthetase domain at the C-terminus. It was suggested that the SufE domain is dedicated to the formation of the [4Fe- $4 \mathrm{~S}]$ cluster bound by the NadA domain [53]. If we except its presence in a few heterokonts, the SUFE3 protein is only present in the green lineage, e.g., Chlorophytes, Streptophytes and Tracheophytes. It would be interesting to determine whether both SUFE1 and SUFE3 interact with both class II CDs. Concerning the scaffold SUFBCD complex, all microalgae possess genes coding for these three proteins except in three organisms in which one gene is apparently missing (Table 2). However, from this high and widespread conservation, we suspect this could in fact be due to a mis-annotation, even though we have not yet been able to identify the corresponding coding sequences in the genomic sequences.

More noticeable differences are observed among putative Fe-S cluster transfer proteins. First, there is a set of four genes/proteins, SUFA1, GRX3, NFU2 and HCF101, that is present in almost all organisms (Table 2). We could not identify HCF101 in one species only (Picocystis sp. ML), which again raises questions about the validity of this observation. GRX6/GRXS16 orthologs are less evenly distributed, almost never being present outside the green lineage (Chlorophytes and Streptophytes). Concerning the two putative chloroplastic BOLA proteins, here renamed BOL1 and BOL3 (to follow the new nomenclature rules adopted for $C$. reinhardtii), the analyzed organisms possess at least one isoform except in Heterokonts and Alveolates. The absence of BOLA proteins in these organisms is surprising considering the strong co-occurrence existing with GRX [54]. In mitochondria from eukaryotes, the role of IBA57 is closely linked to the ATC proteins (ISCA1/2). Land plants also have this gene referred to as IBA57.1, but most of them also have a second IBA57 gene (with the notable exception of monocots) coding for a chloroplastic isoform according to the presence of an ortholog in cyanobacteria [55]. Although a physiological connection between the chloroplastic SUFA1 and IBA57.2 counterparts has not been documented yet, it is surprising that the phylogenetic distribution of IBA57.2 does not follow the one 
of SUFA1, being likely absent in several species. The hypothesis of a dual targeting to chloroplasts and mitochondria made for the orthologs in monocot species (but not verified yet) may also be true for some algal orthologs.

Finally, the most striking difference between terrestrial plants and algae is for chloroplastic NFU proteins. As already stated, there is only one NFU2/3 representative in C. reinhardtii, instead of the two in Arabidopsis and many other terrestrial plants (Table 2). More importantly, CrNFU1 has an atypical domain architecture formed by an N-terminal so-called GIY-YIG domain, which is the catalytic domain present in some endonucleases, fused to the usual NFU domain possessing the cysteines serving for Fe-S cluster binding. Hence, it lacks the second degenerated NFU domain normally present in chloroplastic NFUs. Proteins with a similar architecture are present in many of the microalgae analyzed, but not all, and with no clear pattern of distribution. Interestingly, orthologs are present in all terrestrial plants (including bryophytes and gymnosperms) except dicots. It is noticeable that a similar GIY-YIG domain of unknown function is also present in the N-terminal region of GRX6. In this case, the additional domain has been conserved in dicots as well.

\section{Fe-S Protein-Dependent Metabolic Processes in Algal Chloroplasts}

Known Fe-S proteins present in plastids of land plants and their associated functions have recently been reviewed [5], and Chlamydomonas orthologs will not be systematically described here. However, generally speaking, most important metabolic pathways occurring in chloroplasts are dependent on one or several Fe-S proteins, not to mention proteins dependent on the (2Fe-2S)-containing FDXs. It is worth noting that Chlamydomonas and other close Chlorophyceae (Volvox carteri and Gonium pectorale) possess 12 genes coding for chloroplastic FDXs [56,57], which far surpasses the content of FDX genes in land plants, with six genes being present, for instance, in Arabidopsis [5]. We direct the reader to the following recent review to learn more about the known functions of some Chlamydomonas FDXs [57]. In the following subsections, we will focus rather on Fe-S protein-dependent pathways that are specific to Chlamydomonas or for which Chlamydomonas presents specificities compared to terrestrial plants.

\subsection{Fe-S Proteins Connected to the Photosynthetic Electron Transfer Reactions \\ 3.1.1. Synthesis of Isoprenoids: Fe-S Dependent vs. Independent Pathways}

The ability to synthesize isopentenyl diphosphate, the 5-carbon structure necessary for isoprenoid formation, is essential in all organisms, because isoprenoid-derived molecules include sterols, dolichol, and coenzyme $\mathrm{Q}$, as well as plastoquinones, carotenoids and chlorophylls, which are particularly relevant to the topic of photosynthesis. Isoprenoid synthesis relies on two pathways, the mevalonate (MVA) pathway, which does not involve Fe-S proteins, and the 2-C-methyl-d-erythritol 4-phosphate (MEP) pathway, which requires two proteins with (4Fe-4S) clusters: (E)-4-hydroxy-3-methylbut-2-enyl diphosphate synthase (HDS, ISPG) and 4-hydroxy-3-methylbut-2-en-1-yl diphosphate reductase (HDR, ISPH). The MVA pathway is present in animals, fungi and archaea, the MEP pathway is present in nearly all bacteria [58]. Plants have usually retained both pathways. Most of the plant-specific isoprenoids, such as phytols and carotenoids, are synthesized in plastids by the MEP pathway inherited from the cyanobacterium endosymbiont [58-60], while the cytosolic MVA pathway contributes to sterol synthesis [61]. The situation is variable in microalgae. In Archaeplastids, Charophytes possess both pathways but Chlorophytes and some Rhodophytes rely only on the MEP pathway for isoprenoid synthesis, although the HMG-CoA synthase, the second enzyme of the MVA pathway, is present in some of them $[58,60]$. For algae with secondary endosymbiosis, diatoms and Euglena gracilis kept both pathways [61,62], while only the MEP pathway is present in Nannochloropis oceanica, although a HMG-CoA synthase is also present in this alga [63]. Finally, dinoflagellates only use the MEP pathway [64]. In conclusion, for isoprenoid synthesis, microalgae use either the two pathways like in plants, or only the cyanobacterial Fe-S cluster-dependent 
type. The reason for the loss of the MVA pathway or the presence of both pathways is presently unknown.

\subsubsection{Dark-Operative Protochlorophyllide $a$ Oxidoreductase}

The reduction of protochlorophyllide into chlorophyllide $a$ is the penultimate step of chlorophyll $a$ biosynthesis. This step is catalyzed by two enzymes, the light-dependent protochlorophyllide $a$ oxidoreductase (LPOR) and the dark-operative protochlorophyllide $a$ oxidoreductase (DPOR). LPOR is encoded by one or several nuclear genes (POR genes) and uses NADPH as an electron donor in the presence of light for the reduction of the C17-C18 double bond (reviewed in [65]). The holocomplex is proposed to be dimeric [66]. The DPOR protein is a complex formed by the $\mathrm{L}, \mathrm{N}$ and $\mathrm{B}$ subunits encoded in the chloroplast genome by the chlL, chlN and chlB genes. A crystal structure of the $360 \mathrm{kDa}$ DPOR complex from the cyanobacterium Prochlorococcus marinus indicates that it is a hetero-octameric complex $\left(\mathrm{L}_{2}\right)_{2}(\mathrm{NB})_{2}$ containing four $(4 \mathrm{Fe}-4 \mathrm{~S})$ clusters [67]. The $\mathrm{L}_{2}$ domain is the ATP-dependent reductase component for the catalytic NB domain, where protochlorophyllide reduction takes place using reduced FDX as an electron donor [67]. DPOR is believed to have evolved from a nitrogenase-like enzyme of anoxygenic photosynthetic bacteria, while LPOR arose in cyanobacteria in an oxygenic environment [68]. As a matter of fact, the Klebsiella pneumoniae nitrogenase Fe protein gene (nifH) functionally substitutes for the chlL gene in the green microalga C. reinhardtii [69] in which the absence of ChlL or B subunits leads to a "yellow in the dark" phenotype [70,71]. DPOR has been lost multiple times during evolution and is absent in angiosperms and some gymnosperms. In microalgae, its presence is variable among and within the different lineages, as exemplified in Table 3.

Table 3. Genomic analysis of the occurrence of chloroplast-encoded DPOR and NDH genes in microalgae. Taxonomy is based on [49] and https:/ / www.ncbi.nlm.nih.gov/Taxonomy/Browser/ (accessed on 10 March 2021). a: the Cyanophora paradoxa chloroplast genome sequence is found under the NCBI Reference Sequence: NC_001675. For DPOR, the presence of chlL, N, B genes in the chloroplast genome was systematically analyzed. * indicates the presence of 2 chlL and chlN genes. $\sharp$ indicates the presence of pseudogenes.

\begin{tabular}{|c|c|c|c|c|c|}
\hline Supergroup & Phylum & Class & DPOR & NDH & Refs \\
\hline \multirow{8}{*}{ Archaeplastida } & Glaucophyta & $\begin{array}{l}\text { Glaucocystophyceae } \\
\text { Cyanophora paradoxa }\end{array}$ & + & - & a \\
\hline & Rhodophyta & $\begin{array}{l}\text { Bangiophyceae } \\
\text { Galdieria sulphuraria } \\
\text { Cyanidioschizon merolae } \\
\text { Porphyra purpurea }\end{array}$ & $\begin{array}{l}+ \\
- \\
+\end{array}$ & $\begin{array}{l}- \\
- \\
-\end{array}$ & $\begin{array}{l}{[72]} \\
{[73]} \\
{[74]}\end{array}$ \\
\hline & \multirow{5}{*}{ Chlorophyta } & $\begin{array}{c}\text { Mamiellophyceae } \\
\text { Ostreococcus tauri } \\
\text { Nephroselmidophyceae }\end{array}$ & - & - & {$[75]$} \\
\hline & & $\begin{array}{l}\text { Nephroselmis astigmatica } \\
\text { Picocystophyceae }\end{array}$ & $+^{*}$ & - & {$[76]$} \\
\hline & & $\begin{array}{c}\text { Picocystis salinarum } \\
\text { Chlorophyceae }\end{array}$ & - & + & [76] \\
\hline & & $\begin{array}{c}\text { Chlamydomonas reinhardtii } \\
\text { Trebouxiophyceae }\end{array}$ & + & - & [77] \\
\hline & & Chlorella vulgaris & + & - & [78] \\
\hline & Streptophyta & $\begin{array}{l}\text { Klebsormidiaceae } \\
\text { Klebsormidium flaccidum } \\
\text { Maesotaenium } \\
\text { endlicherianum } \\
\text { Charophyceae } \\
\text { Chara vulgaris }\end{array}$ & $\begin{array}{l}+ \\
+\end{array}$ & $\begin{array}{l}+ \\
+\end{array}$ & $\begin{array}{l}{[79]} \\
{[79]} \\
{[80]}\end{array}$ \\
\hline
\end{tabular}


Table 3. Cont.

\begin{tabular}{|c|c|c|c|c|c|}
\hline Supergroup & Phylum & Class & DPOR & NDH & Refs \\
\hline \multirow{5}{*}{ Heterokonta } & \multirow{5}{*}{ Ochrophyta } & Bacillariophyceae & & & \\
\hline & & Phaeodactylum tricornutum & - & - & [81] \\
\hline & & Coscinodiscophyceae & & & \\
\hline & & $\begin{array}{c}\text { Thalassiosira pseudonana } \\
\text { Eustigmatophyceae }\end{array}$ & - & - & [81] \\
\hline & & $\begin{array}{c}\text { Nannochloropsis oceanica } \\
\text { IMET1 }\end{array}$ & + & - & [82] \\
\hline \multirow{3}{*}{ Alveolata } & Dinophyta & $\begin{array}{c}\text { Dinophyceae } \\
\text { Symbiodinium Clade C3 }\end{array}$ & - & - & [83] \\
\hline & \multirow[t]{2}{*}{ Chromerida } & $\begin{array}{l}\text { Vitrella brassicaformis } \\
\text { CCMP3155 }\end{array}$ & $+^{*}$ & - & {$[50]$} \\
\hline & & Chromera velia & - & - & [50] \\
\hline \multirow{3}{*}{ Rhizaria } & \multirow{3}{*}{ Cercozoa } & Chlorarachniophyceae & & & \\
\hline & & Bigelowiella natans & - & - & [84] \\
\hline & & Lotharella oceanica & - & - & [85] \\
\hline \multirow{3}{*}{ Haptophyta } & & Prymnesiophyceae & & & \\
\hline & & Emiliania huxleyi & - & - & [86] \\
\hline & & Tisochrysis lutea & - & - & [87] \\
\hline \multirow{4}{*}{ Cryptophyta } & & \multirow{4}{*}{$\begin{array}{c}\text { Cryptophyceae } \\
\text { Guillardia theta CCMP2712 } \\
\text { Rhodomonas salina } \\
\text { CCMP1319 } \\
\text { Storeatula species } \\
\text { CCMP1868 }\end{array}$} & & & \\
\hline & & & - & - & [88] \\
\hline & & & $-\sharp$ & - & [89] \\
\hline & & & + & - & [90] \\
\hline \multirow{3}{*}{ Excavata } & \multirow{3}{*}{ Euglenozoa } & Euglenophyceae & & & \\
\hline & & Euglena gracilis & - & - & [91] \\
\hline & & Eutreptiella pomquetensis & - & - & [92] \\
\hline
\end{tabular}

The chlL, chlN and $c h l B$ genes are not present in any of the chloroplast genomes sequenced in the Chlorarachniophytes, Haptophytes and Euglenophyceae, suggesting that these genes were lost early, while these lineages were settling [93]. Other groups present lineages and species with or without these genes (see Table 3, [90,93]). In Cryptophytes, some species even possess pseudogenes in the chloroplast genome, which suggests that the process of loss is still occurring in this group [90]. When DPOR is present, only one $P O R$ gene is usually present, while multiple POR genes are often present in species lacking DPOR [93]. Concerning the light spectrum, the protochlorophyllide pigment is absorbed in both the blue and the red regions, but its photoconversion by LPOR would be much more efficient when red light is applied. Since red light is rapidly attenuated in water, activity of the LPOR enzyme would be much less efficient in deep, turbid waters, while DPOR is insensitive to the light (discussed in [93]). This would explain why the presence of DPOR would be beneficial for microalgae living in deep, turbid waters, which is the case of freshwater species. Indeed, chlL, chlN and chlB genes are usually found in Chlorophytes such as in the freshwater C. reinhardtii (Table 3) [75]. One exception has, however, recently been described in the Chlorophycean class: a psychrophilic Chlamydomonas strain (UWO241) in which the absence of DPOR could be linked to the high oxygen concentration in the water layer of Lake Bonney in Antarctica, where this isolate lives, considering the sensitivity of the Fe-S clusters of DPOR to oxygen [94]. In addition to its proposed sensitivity towards $\mathrm{O}_{2}$, DPOR would also be counter-selected in oceans where Fe is limiting. As a matter of fact, diatoms such as P. tricornutum and Thalassiosira pseudonana do not have DPOR, but other oceanic species, such as N. oceanica, do. 


\subsubsection{Type I NADH Dehydrogenase in Microalgae}

The type I NADH dehydrogenase (NDH-1) is a minor component of the photosynthetic chain in land plants, inherited from cyanobacteria. In plants, it comprises 11 subunits encoded in the chloroplast genome (NdhA-K) with NdhI and NdhK binding (4Fe-4S) clusters and more than 19 subunits encoded in the nucleus [95]. Although pioneer works proposed that plastidial NDH-1 would oxidize NADH or NADPH, more recent studies have suggested that the enzyme would accept electrons from FDX [96]. The detailed analysis of its proposed function in cyanobacteria and in land plants is reviewed in [95], and the crystal structure of the Thermosynechococcus elongatus NDH-I was recently published, confirming that the enzyme oxidizes FDX instead of $\mathrm{NAD}(\mathrm{P}) \mathrm{H}[7,96]$. Most of the microalgae did not retain this multimeric complex in their photosynthetic chain. The $N d h$ genes are still present in the chloroplast genome of some Chlorophytes $[76,80]$ and in Charophytes, the closest relatives to land plants (Table 3) (reviewed in [97]). In the green microalga Chlamydomonas, there is no gene coding for NDH subunits in the chloroplast genome, but a nuclear-encoded monomeric type II NADH dehydrogenase (NDH-2) (Nda2) exists in chloroplast. This enzyme is involved in the non-photochemical reduction of the plastoquinone (PQ) pool by using NADH or NADPH as electron donor, and one FMN as cofactor $[98,99]$. This enzyme would participate in chlororespiration, together with the plastid terminal oxidase 2 (PTOX2), to reduce $\mathrm{O}_{2}$ into $\mathrm{H}_{2} \mathrm{O}$. Chlororespiration would be involved in the dissipation of the excess of reducing equivalents originating from both light-induced processes and carbon metabolism when electron flow downstream of the PQ pool is compromised (reviewed in [100]). CrNDA2 would also be involved in $\mathrm{H}_{2}$ photoproduction $[98,101]$.

\subsubsection{Photosystem II Protein 33}

Photosystem II protein 33 (PSB33) is part of the Greencut, i.e., the set of proteins specific to organisms of the green lineage [102]. It is a transmembrane protein associated with thylakoid membranes, which is involved in the fine-tuning of light harvesting and/or energy transfer around both photosystems in A. thaliana $[103,104]$. Some green algae possess a PSB33 ortholog including Chlamydomonas (Cre09.g411200, TEF5), but also a closely related protein (PSB33-like, Cre02.g093650) assumed to be soluble because it lacks the transmembrane domain. There is no ortholog of this PSB33-like protein in land plants. It is predicted to bind a (2Fe-2S) Rieske-type cluster owing to the presence of $\mathrm{CxH}$ and $\mathrm{CxxH}$ motifs that are conserved in cyanobacterial orthologs. Although the transcript abundance of this PSB33-like protein is increased under low-Fe conditions [105], whether this protein indeed binds an Fe-S cluster and whether this is important for its function, which is yet unknown, remains to be explored. Finally, it is highly uncertain that transmembrane PSB33 proteins have the capacity to bind an Fe-S cluster since only the cysteine of the second motif is conserved.

\subsubsection{Chloroplast Sensor Kinase}

The chloroplast sensor kinase (CSK) is a histidine kinase that is proposed to regulate photosystem gene expression in the chloroplast. The recent biochemical characterization of recombinant A. thaliana, P. tricornutum and Synechocystis sp. PCC 6803 CSK showed that it binds a [3Fe-4S] cluster that would be sensitive to the redox state of the PQ pool [106]. It is proposed that upon specific light excitation of PSII, the [3Fe-4S] cluster is reduced by $\mathrm{PQH}_{2}$, which would inactivate the kinase. When the $\mathrm{PQ}$ pool is oxidized by specific excitation of PSI, the [3Fe-4S] cluster of CSK would be reoxidized by oxygen, and CSK would be activated to regulate chloroplast gene expression. The sequence conservation is so weak among these proteins that it hampered to determine whether orthologs are present in other algae. 


\subsection{Contribution of Fe-S Enzymes to the Fermentative Metabolism}

Microalgae encounter periods of hypoxic/anoxic phases when $\mathrm{O}_{2}$ availability becomes limited. This happens in the dark (i.e., notably during the night), when $\mathrm{O}_{2}$ produced by photosynthetic activity decreases because of respiratory activity, or in the light, when heterotrophic microbial communities exceed those that are photosynthetic. In addition, some species of the Chlamydomonas genus even constantly live in anoxic biotopes such as in peat bogs and sewage lagoons [107], which may explain why this microalga has a particularly well-developed fermentative metabolism, essentially taking place in the chloroplast. Basically, glucose generated by starch hydrolysis is oxidized into pyruvate, leading to the generation of ATP and NADH. Under anaerobiosis, in the absence of a functional tricarboxylic acid cycle, NADH must be oxidized by fermentation processes to maintain the glycolytic flux, energy production and survival in the dark. The fermentative metabolism under dark anaerobic conditions has been quite well described in $C$. reinhardtii, where the various pathways (Figure 2) lead to the excretion in the medium of formate, acetate, and ethanol as major organic products, while $\mathrm{CO}_{2}$ and $\mathrm{H}_{2}$ are generated as minor gaseous products (extensively reviewed in [108-110]). Chlamydomonas has two enzymes performing the conversion of pyruvate into acetyl-CoA under anaerobiosis: pyruvate-formate lyase (PFL) and pyruvate-ferredoxin oxidoreductase (PFO) (Figure 2). PFL catalyzes the conversion of pyruvate into acetyl-CoA and formate, while PFO catalyzes the oxidation of pyruvate into acetyl-CoA and $\mathrm{CO}_{2}$, with simultaneous reduction of FDX. Reduced FDX can be reoxidized by hydrogenases (HYDs), leading to the formation of dihydrogen $\left(\mathrm{H}_{2}\right)$. It has also been proposed that sulfite reductases (SIRs), nitrite reductases (NIRs), and hybrid cluster proteins (HCPs) [111] could also participate in the reoxidation of FDX under anaerobiosis. The acetyl-CoA produced by PFL and PFO is either reduced to ethanol by alcohol/aldehyde dehydrogenase (ADH) or converted into acetate by the phosphoacetyltransferase-acetate kinase (PAT-ACK) pathway [108]. The PAT-ACK pathway is present in both chloroplast and mitochondria. PAT and ACK are encoded by two distinct genes for the two organelles (PAT1, ACK2 in mitochondria; PAT2-ACK1 in chloroplast), while PFL is encoded by a single nuclear gene (PFL1), but is dually targeted to both mitochondria and chloroplast [52,112]. This route provides ATP, but does not eliminate reductants. Another route for ethanol production consists of the decarboxylation of pyruvate by pyruvate decarboxylase (PDC) into $\mathrm{CO}_{2}$ and acetaldehyde, which is then reduced into ethanol by ADH. Enzymes bearing Fe-S clusters are shown in red in Figure 2 and are described in the following subsections. 


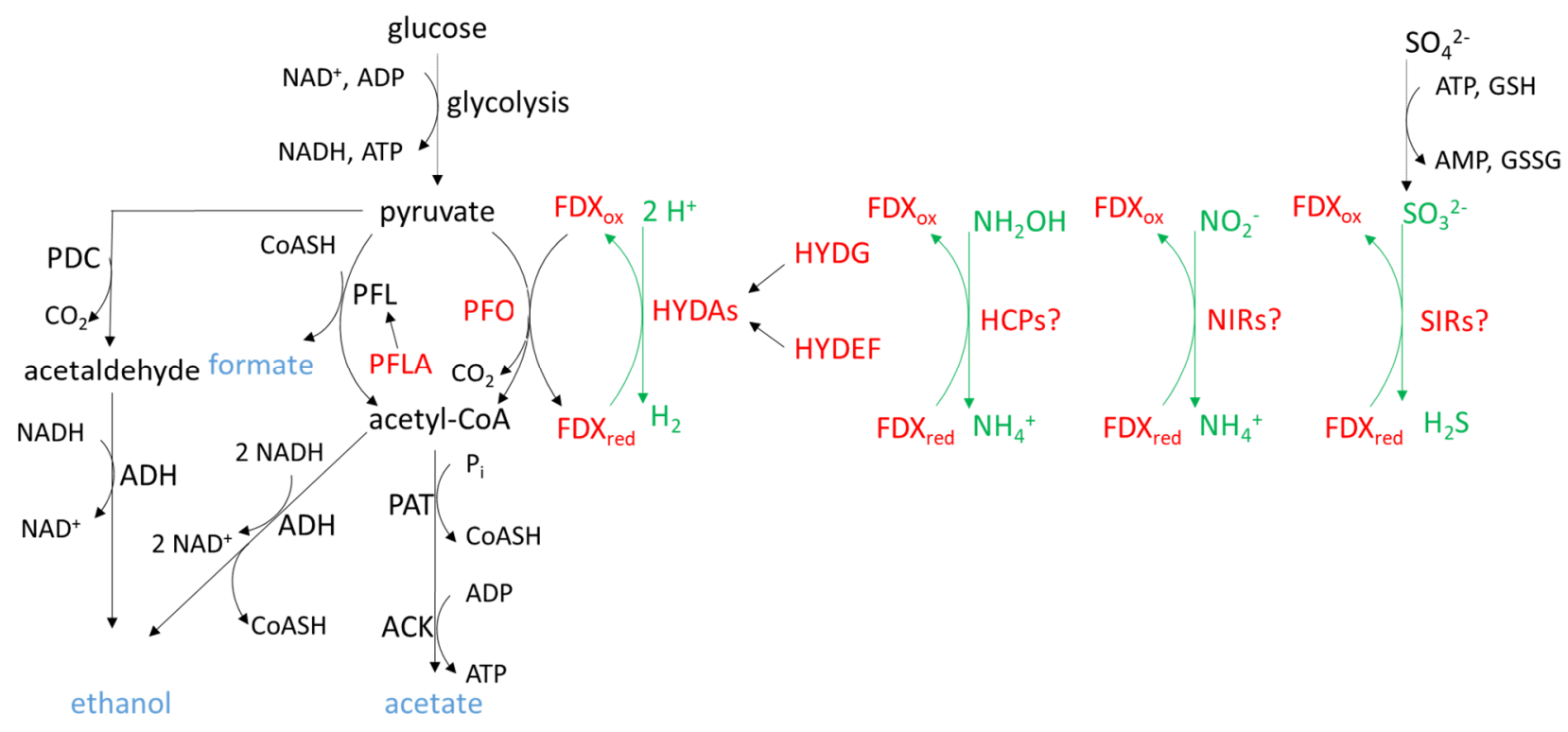

Figure 2. Major fermentation pathways in C. reinhardtii. ACK: acetate kinase; ADH: alcohol/aldehyde dehydrogenase; FDX: ferredoxin; GSH: reduced glutathione; GSSG: glutathione disulfide; HYDAs: hydrogenases; HYDEF and HYDG: maturases of hydrogenases; HCPs: hybrid cluster proteins; NIRs: nitrite reductases; PAT: phosphoacetyltransferase; PDC: pyruvate decarboxylase; PFL: pyruvate-formate lyase; PFLA: pyruvate-formate lyase activating enzyme; PFO: pyruvate-ferredoxin oxidoreductase; SIRs: sulfite reductases. Fe-S enzymes are in red. The four putative pathways serving for ferredoxin oxidation are in green. Adapted from [108,111].

\subsubsection{Pyruvate-Formate Lyase Activating Enzyme}

PFL is converted post-translationally from an inactive to an active form by a $\sim 20 \mathrm{kDa}$ protein, namely the pyruvate-formate lyase activating enzyme (PFLA). This radical Sadenosyl-L-methionine (SAM) enzyme introduces a radical ( $\mathrm{H}$ atom abstraction) on the ultimate glycine residue of the PFL $[113,114]$. Molecular oxygen irreversibly inactivates the radical active form of PFL [115]. Like most radical SAM enzymes, PFLA possesses the usual $\mathrm{CX}_{3} \mathrm{CX}_{2} \mathrm{C}$ motif by which the conserved cysteines coordinate three Fe atoms of the (4Fe-4S) cluster while SAM coordinates the fourth Fe atom [114]. PFLA is present in an inactive form under aerobic conditions and is allosterically activated by pyruvate [116]. The Chlamydomonas PFLA is predicted to be targeted to the chloroplast, according to the presence of a characteristic N-terminal extension [112].

\subsubsection{Pyruvate-Ferredoxin Oxidoreductase}

Chlamydomonas PFO is a large enzyme of $128 \mathrm{kDa}$ binding three (4Fe-4S) clusters into a homodimer $[117,118]$. In addition to the cysteine-binding motifs, there is a YPITP motif at the N-terminal part of the protein [119] that would be involved in the turnover of the reaction and a motif for binding a thiamine pyrophosphate cofactor, essential for the decarboxylation reaction, at the C-terminal part. Because the synthesis of thiamine relies on an Fe-S protein, the synthesis of an active holo-PFO enzyme is doubly dependent on a functional SUF maturation system.

\subsubsection{Hydrogenases and Their Maturation Factors}

In Chlamydomonas, two genes, HYDA1 and HYDA2, encode a [Fe-Fe] hydrogenase. HYDA1 and HYDA2 amino acid sequences are very close to each other (73\% identity), and HYDA1 is the major contributor of $\mathrm{H}_{2}$ production (75\%) [120]. The catalytic site of the HYDA1 enzyme contains a complex Fe-S cluster named the H-cluster that is composed of a classical $(4 \mathrm{Fe}-4 \mathrm{~S})$ cluster bridged by a cysteine thiolate to a unique $2 \mathrm{Fe}$ sub-cluster in which two Fe atoms are coordinated by three $\mathrm{CO}$ - and two $\mathrm{CN}$ - ligands, as well as 
an azadithiolate bridge [121-124]. It is suggested that the (4Fe-4S) cluster is inserted by the SUF assembly machinery followed by the $2 \mathrm{Fe}$ sub-cluster, whose biosynthesis requires the specific HYDE, HYDF and HYDG maturases, with the HYDE and HYDG being two radical SAM proteins binding (4Fe-4S) clusters [125-127]. In Chlamydomonas, the HYDE and HYDF maturases are fused as a chimeric protein, whereas these are separate genes/enzymes in some microalgae [128,129]. HYDE and HYDG synthesize the nonprotein ligands, and HYDF is an Fe-S cluster binding and GTPase-domain containing protein that provides the scaffold for the assembly of the $2 \mathrm{Fe}$ sub-cluster of the $\mathrm{H}$ domain before its insertion in the hydrogenase [124].

\subsubsection{Hybrid Cluster Protein}

HCPs bear two different types of Fe-S clusters: a classical (4Fe-4S) cluster and a (4Fe-2O-2S) hybrid cluster. Crystal structures have been obtained in two Desulfovibrio species [130-132] in which the conserved cysteines for the binding of the (4Fe-4S) cluster are present in the N-terminal part while the ligands for the binding of the hybrid cluster are scattered elsewhere. In Chlamydomonas, four genes (HCP1-HCP4) encode HCP proteins. The phylogenetic analyses suggest that $H C P$ genes arose from a single gene of alpha-proteobacterial origin followed by subsequent duplications. These duplications are very specific to Chlamydomonas, since most microalgae analyzed have a single gene, with some species, including Volvox carteri, having two genes. Chlamydomonas HCP1, 3 and 4 would be targeted to the chloroplast, while HCP2 would be localized in mitochondria [133]. Nitrate and darkness are responsible for increased levels of the proteins in oxic conditions [133]. The HCP4 transcript level is increased in dark anoxia [134]. Characterization of a Chlamydomonas hcp 4 mutant obtained by miRNA suggests that the corresponding protein could be involved in FDX oxidation (Figure 2) as a putative hydroxylamine reductase, competing with hydrogenase for electrons from reduced FDX [111].

\subsubsection{Sulfite Reductase}

In plants, SIR participates to sulfate assimilation and catalyzes the reduction of sulfite to sulfide using reduced FDX as electron donor. It contains a siroheme linked to a (4Fe-4S) cluster, and a series of crystal structures has revealed how FDX binds to the catalytic site of the plant enzyme (reviewed in [135]). While there is a single essential gene in Arabidopsis, three SIR genes (SIR1, SIR2, SIR3) are present in Chlamydomonas. SIR1 is predicted to be localized to the chloroplast by Target-P, while the other two proteins would not be localized in organelles. SIR1 transcript level (Cre16.g693202) is increased in dark anaerobiosis conditions [134], suggesting that SIR1 could also compete with hydrogenase for reduced FDX.

\subsubsection{Fermentative Pathways in Other Microalgae}

Other freshwater green microalgae also perform anaerobic fermentation of starch [108], but $C$. reinhardtii is by far the best characterized species. Table 4 presents the Fe-S enzymes of the anaerobic metabolism found among microalgae of diverse phylogenetic origin. Fe-S cluster enzymes participating in anaerobic metabolism seem absent in two classes (Rhodophytes and Haptophytes), while the other groups present at least one representative Fe-S enzyme. The complete set of enzymes participating in the anaerobic metabolism is described in [108]. Marine species such as diatoms and dinoflagellates survive in dark anoxic conditions when they sink in the oceans [136]. Diatoms can use nitrate for dissimilatory nitrate reduction to ammonium (DNRA) [137-139], which allows NAD(P)+ regeneration and maintains the glycolytic flux [140]. DNRA proceeds as follows: nitrate is accumulated inside the cells converted into nitrite by nitrate reductase. Nitrite can be reduced into ammonium by nitrite reductase (NIR) inside the chloroplast, under dark anoxic conditions. NIR is a siroheme protein bearing a (4Fe-4S) cluster using reduced FDX as electron donor and may thus also be considered as a competitor to hydrogenase for FDX if hydrogen is produced as a fermentative product by the microalga. This could be the case 
of the diatom T. pseudonana, where a gene encoding a hydrogenase has been found in the nuclear genome although the maturation factors could not be identified (Table 4) [108].

Table 4. Distribution of genes encoding Fe-S enzymes involved in the anaerobic metabolism of microalgae. Sequences were retrieved in 25 species from Phycocosm (https:/ / phycocosm.jgi.doe.gov/phycocosm/home (accessed on 10 March 2021)) using C. reinhardtii sequences and blastp or tblastn searches [10]. The sequences are available as supplementary information. a: fused HYDEF genes; b: the sequence is not present in Phaeodactylum tricornutum but is present in Thalassiosira pseudonana; c: the sequence is present in Chlorella variabilis but not in all Trebouxiophyceae; $\mathrm{d}$ : the HCP gene is fused to a gene coding for sulfite reductase. In Tetraselmis, a HYDE gene exists in addition to the fused HYDEF genes [128]. Notably, we cannot exclude that sequences in some of the automatically annotated genomes analyzed were reported as missing because of problems in the genome assembly.

\begin{tabular}{|c|c|c|c|c|c|c|c|c|c|}
\hline & & & PFLA & PFO & HYDA & HYDE & HYDF & HYDG & HCP \\
\hline Rhodophyta & & Galdieria sulphuraria $074 \mathrm{~W}$ & & & & & & & \\
\hline Glaucophyta & & $\begin{array}{c}\text { Cyanophora paradoxa } \\
\text { CCMP329 }\end{array}$ & + & + & + & + & + & + &,$+ \mathrm{d}$ \\
\hline \multirow[t]{7}{*}{ Chlorophyta } & $\begin{array}{l}\text { Chlorophyceae } \\
\text { Ulvophyceae }\end{array}$ & $\begin{array}{l}\text { Chlamydomonas reinhardtii } \\
\text { Caulerpa lentillifera }\end{array}$ & $\begin{array}{l}+ \\
+\end{array}$ & + & + &,$+ \mathrm{a}$ &,$+ \mathrm{a}$ & + & + \\
\hline & Trebouxiophyceae & Chlorella variabilis NC64A & + &,$+ \mathrm{c}$ & + &,$+ \mathrm{a}$ &,$+ \mathrm{a}$ & + &,$+ \mathrm{c}$ \\
\hline & Chlorodendrophyceae & Tetraselmis striata & + & + & + &,$+ \mathrm{a}$ &,$+ \mathrm{a}$ & & \\
\hline & Chloropicophyceae & Chloropicon primus & & & & & & & \\
\hline & Picocystophyceae & Picocystis sp. ML & & & & & & & \\
\hline & Mamiellophyceae & Micromonas pusilla CCMP1545 & + & & & & & & \\
\hline & Palmophyllophyceae & $\begin{array}{c}\text { Prasinoderma coloniale } \\
\text { CCMP1413 }\end{array}$ & & & & & & & \\
\hline \multirow[t]{5}{*}{ Streptophyta } & Chlorokybophyceae & $\begin{array}{l}\text { Chlorokybus atmophyticus } \\
\text { CCAC } 0220\end{array}$ & & & & & & & \\
\hline & Mesostigmatophyceae & Mesostigma viride CCAC 1140 & & & & & & & + \\
\hline & Klebsormidiophyceae & $\begin{array}{l}\text { Klebsormidium nitens } \\
\text { NIES-2285 }\end{array}$ & & & & & & & \\
\hline & Zygnemophyceae & $\begin{array}{l}\text { Mesotaenium endlicherianum } \\
\text { SAG } 12.97\end{array}$ & & & & & & & \\
\hline & Charophyceae & Chara braunii S276 & + & & + & + & + & + & + \\
\hline Cryptophyta & & Guillardia theta CCMP2712 & & + & & & & & + \\
\hline Haptophyta & & $\begin{array}{c}\text { Emiliania huxleyi } \\
\text { CCMP1516 v1.0 }\end{array}$ & & & & & & & \\
\hline Rhizaria & Chlorarachniophyta & Bigelowiella natans CCMP2755 & + & & & & & & \\
\hline \multirow[t]{5}{*}{ Heterokonta } & Bacillariophyta & $\begin{array}{c}\text { Phaeodactylum tricornutum } \\
\text { CCAP 1055/1 v2.0 }\end{array}$ & $\mathrm{b}$ & $\mathrm{b}$ & $\mathrm{b}$ & & & & + \\
\hline & Phaeophyta & Ectocarpus siliculosus Ec 32 & & & & & & & \\
\hline & Eustigmatophyta & $\begin{array}{c}\text { Nannochloropsis oceanica } \\
\text { CCMP1779 v2.0 }\end{array}$ & & & + & + & + & + & + \\
\hline & Chrysophyta & $\begin{array}{l}\text { Ochromonas sp. } \\
\text { CCMP1393 v1.4 }\end{array}$ & & & & & & & + \\
\hline & Pelagophyta & $\begin{array}{c}\text { Aureococcus anophagefferens } \\
\text { clone } 1984\end{array}$ & & & & & & & \\
\hline \multirow[t]{2}{*}{ Alveolata } & Chromerida & $\begin{array}{l}\text { Vitrella brassicaformis } \\
\text { CCMP3155 }\end{array}$ & + & + & + &,$+ \mathrm{a}$ &,$+ \mathrm{a}$ & + & + \\
\hline & Dinophyta & $\begin{array}{c}\text { Symbiodinium } \\
\text { microadriaticum CCMP2467 }\end{array}$ & & + & & & & & + \\
\hline
\end{tabular}

\section{Conclusions}

In summary, the SUF machinery, dedicated to the maturation of chloroplastic Fe-S proteins, is present in all supergroups of microalgae performing oxygenic photosynthesis. However, particularities exist compared to terrestrial plants, notably in the sulfur mobilization system with the presence of an additional class II cysteine desulfurase in some organisms, which is surprisingly accompanied by a reduced number and diversity of SUFE proteins. The scaffold SUFBCD proteins are almost ubiquitously present, with no apparent specificity. Some variations exist at the level of Fe-S cluster transfer proteins. While the SUFA1, NFU2, GRX3 and HCF101 proteins are ubiquitously present in microalgae analyzed, differences are visible for IBA57.2, NFU1, GRX6 and the BOLA family. Many algae outside the green lineage lack BOLA proteins and have a single GRX representative. Concerning Fe-S proteins, it appears that the living environment or ecological niche of some microalgae have a strong impact on some metabolic pathways. It has already been noticed that the progressive adaptation of the aquatic (and terrestrial) life at increasing $\mathrm{O}_{2}$ concentrations was accompanied by several changes in terms of the oxido-reduction metabolism, such as the appearance of Fe-S cluster-free, oxygen-resistant proteins (whereas "ancestor" proteins had Fe-S clusters) or the transition from a ferredoxin to a NADPH- and flavin-dependent redox 
metabolism [141]. Still, despite possessing an $\mathrm{O}_{2}$-dependent energy metabolism, some microalgae such as $C$. reinhardtii, but not all, have retained a developed anaerobic energy metabolism to cope with anoxic/hypoxic conditions that relies on $\mathrm{O}_{2}$-sensitive Fe-S cluster containing-enzymes (Fe-Fe hydrogenases, PFO). Variations among microalgae are also visible when considering chlorophyll biosynthesis. Within supergroups, some taxa have retained an Fe-S cluster-dependent dark-operative protochlorophyllide $a$ oxidoreductase in addition to the NADPH-dependent light-dependent protochlorophyllide $a$ oxidoreductase. While the three chl genes are typically either entirely present or absent from a chloroplast genome, there are remarkable examples of species having lost only one gene or possessing pseudogenes, suggesting that the process of chl gene loss is currently operating in these organisms [93]. Hence, analyzing the genomic data recently acquired on very diverse algal species [49] will undoubtedly give additional clues about the evolutionary adaptations (loss, acquisition, duplication) of some important metabolic pathways as exemplified in this review.

Supplementary Materials: The following are available online at https:/ / www.mdpi.com/1422-006 $7 / 22 / 6 / 3175 / s 1$

Author Contributions: Bioinformatic analyses, J.P.-T., J.C., C.R., N.R.; Writing-original draft preparation, J.P.-T., C.R, N.R. All authors have read and agreed to the published version of the manuscript.

Funding: The work of JPT and NR is supported by grants from the Agence Nationale de la Recherche as part of the "Investissements d'Avenir" program (ANR-11-LABX-0002-01, Lab of Excellence ARBRE; ANR-15-IDEX-04-LUE, “Lorraine Université d'Excellence”). CR acknowledges FNRS-FWO EOS Project 30829584 and FNRS CDR J.0175.20.

Conflicts of Interest: The authors declare no conflict of interest.

$\begin{array}{ll}\text { Abbreviations } \\ \text { CD } & \text { cysteine desulfurase } \\ \text { CSK } & \begin{array}{l}\text { chloroplast sensor kinase } \\ \text { dark-operative protochlorophyllide } a \text { oxidoreductase }\end{array} \\ \text { DPOR } & \text { ferredoxin } \\ \text { FDX } & \text { iron-sulfur } \\ \text { Fe-S } & \text { glutaredoxin } \\ \text { GRX } & \text { high chlorophyll fluorescence 101 } \\ \text { HCF101 } & \text { hybrid cluster protein } \\ \text { HCP } & \text { hydrogenases } \\ \text { HYD } & \text { light-dependent protochlorophyllide } a \text { oxidoreductase } \\ \text { LPOR } & \text { 2-C-methyl-d-erythritol 4-phosphate } \\ \text { MEP } & \text { multiple resistance and pH adaptation } \\ \text { MRP } & \text { mevalonate } \\ \text { MVA } & \text { NADH dehydrogenase } \\ \text { NDH } & \text { nitrite reductase } \\ \text { NIR } & \text { Pyruvate-formate lyase } \\ \text { PFL } & \text { Pyruvate-ferredoxin oxidoreductase } \\ \text { PFO } & \text { sulfite reductase } \\ \text { SIR } & \text { sulfur mobilization } \\ \text { SUF } & \end{array}$

\section{References}

1. Przybyla-Toscano, J.; Boussardon, C.; Law, S.; Rouhier, N.; Keech, O. Gene Atlas of Iron-Containing Proteins in Arabidopsis thaliana. Plant J. 2021. [CrossRef]

2. Zanello, P. Structure and Electrochemistry of Proteins Harboring Iron-Sulfur Clusters of Different Nuclearities. Part IV. Canonical, Non-Canonical and Hybrid Iron-Sulfur Proteins. J. Struct. Biol. 2019, 205, 103-120. [CrossRef] [PubMed]

3. Lill, R. Function and Biogenesis of Iron-Sulphur Proteins. Nature 2009, 460, 831-838. [CrossRef] [PubMed]

4. Przybyla-Toscano, J.; Christ, L.; Keech, O.; Rouhier, N. Iron-Sulfur Proteins in Plant Mitochondria: Roles and Maturation. J. Exp. Bot. 2020. [CrossRef] 
5. Przybyla-Toscano, J.; Roland, M.; Gaymard, F.; Couturier, J.; Rouhier, N. Roles and Maturation of Iron-Sulfur Proteins in Plastids. J. Biol. Inorg. Chem. 2018, 23, 545-566. [CrossRef] [PubMed]

6. Merchant, S.; Sawaya, M.R. The Light Reactions: A Guide to Recent Acquisitions for the Picture Gallery. Plant Cell 2005, 17, 648-663. [CrossRef] [PubMed]

7. Pan, X.; Cao, D.; Xie, F.; Xu, F.; Su, X.; Mi, H.; Zhang, X.; Li, M. Structural Basis for Electron Transport Mechanism of Complex I-like Photosynthetic Nad(p)h Dehydrogenase. Nat. Commun. 2020, 11, 610. [CrossRef]

8. Hertle, A.P.; Blunder, T.; Wunder, T.; Pesaresi, P.; Pribil, M.; Armbruster, U.; Leister, D. PGRL1 Is the Elusive FerredoxinPlastoquinone Reductase in Photosynthetic Cyclic Electron Flow. Mol. Cell 2013, 49, 511-523. [CrossRef]

9. Yamori, W.; Shikanai, T. Physiological Functions of Cyclic Electron Transport Around Photosystem I in Sustaining Photosynthesis and Plant Growth. Annu. Rev. Plant Biol. 2016, 67, 81-106. [CrossRef] [PubMed]

10. Couturier, J.; Touraine, B.; Briat, J.-F.; Gaymard, F.; Rouhier, N. The Iron-Sulfur Cluster Assembly Machineries in Plants: Current Knowledge and Open Questions. Front. Plant Sci. 2013, 4, 259. [CrossRef]

11. Garcia, P.S.; Gribaldo, S.; Py, B.; Barras, F. The SUF System: An ABC ATPase-Dependent Protein Complex with a Role in Fe-S Cluster Biogenesis. Res. Microbiol. 2019, 170, 426-434. [CrossRef]

12. Boyd, E.S.; Thomas, K.M.; Dai, Y.; Boyd, J.M.; Outten, F.W. Interplay between Oxygen and Fe-S Cluster Biogenesis: Insights from the Suf Pathway. Biochemistry 2014, 53, 5834-5847. [CrossRef]

13. Bai, Y.; Chen, T.; Happe, T.; Lu, Y.; Sawyer, A. Iron-Sulphur Cluster Biogenesis via the SUF Pathway. Metallomics 2018, 10, 1038-1052. [CrossRef] [PubMed]

14. Gao, F. Iron-Sulfur Cluster Biogenesis and Iron Homeostasis in Cyanobacteria. Front. Microbiol. 2020, 11, 165. [CrossRef] [PubMed]

15. Outten, F.W. Recent Advances in the Suf Fe-S Cluster Biogenesis Pathway: Beyond the Proteobacteria. Biochim. Biophys. Acta 2015, 1853, 1464-1469. [CrossRef]

16. Blahut, M.; Sanchez, E.; Fisher, C.E.; Outten, F.W. Fe-S Cluster Biogenesis by the Bacterial Suf Pathway. Biochim. Biophys. Acta Mol. Cell Res. 2020, 1867, 118829. [CrossRef] [PubMed]

17. Braymer, J.J.; Freibert, S.A.; Rakwalska-Bange, M.; Lill, R. Mechanistic Concepts of Iron-Sulfur Protein Biogenesis in Biology. Biochim. Biophys. Acta Mol. Cell Res. 2020, 118863. [CrossRef]

18. Loiseau, L.; Ollagnier-de-Choudens, S.; Nachin, L.; Fontecave, M.; Barras, F. Biogenesis of Fe-S Cluster by the Bacterial Suf System: SufS and SufE Form a New Type of Cysteine Desulfurase. J. Biol. Chem. 2003, 278, 38352-38359. [CrossRef] [PubMed]

19. Outten, F.W.; Wood, M.J.; Munoz, F.M.; Storz, G. The SufE Protein and the SufBCD Complex Enhance SufS Cysteine Desulfurase Activity as Part of a Sulfur Transfer Pathway for Fe-S Cluster Assembly in Escherichia coli. J. Biol. Chem. 2003, 278, 45713-45719. [CrossRef]

20. Ye, H.; Abdel-Ghany, S.E.; Anderson, T.D.; Pilon-Smits, E.A.H.; Pilon, M. CpSufE Activates the Cysteine Desulfurase CpNifS for Chloroplastic Fe-S Cluster Formation. J. Biol. Chem. 2006, 281, 8958-8969. [CrossRef]

21. Black, K.A.; Dos Santos, P.C. Shared-Intermediates in the Biosynthesis of Thio-Cofactors: Mechanism and Functions of Cysteine Desulfurases and Sulfur Acceptors. Biochim. Biophys. Acta 2015, 1853, 1470-1480. [CrossRef]

22. Singh, H.; Dai, Y.; Outten, F.W.; Busenlehner, L.S. Escherichia coli SufE Sulfur Transfer Protein Modulates the SufS Cysteine Desulfurase through Allosteric Conformational Dynamics. J. Biol. Chem. 2013, 288, 36189-36200. [CrossRef] [PubMed]

23. Layer, G.; Gaddam, S.A.; Ayala-Castro, C.N.; Ollagnier-de Choudens, S.; Lascoux, D.; Fontecave, M.; Outten, F.W. SufE Transfers Sulfur from SufS to SufB for Iron-Sulfur Cluster Assembly. J. Biol. Chem. 2007, 282, 13342-13350. [CrossRef]

24. Hirabayashi, K.; Yuda, E.; Tanaka, N.; Katayama, S.; Iwasaki, K.; Matsumoto, T.; Kurisu, G.; Outten, F.W.; Fukuyama, K.; Takahashi, Y.; et al. Functional Dynamics Revealed by the Structure of the SufBCD Complex, a Novel ATP-Binding Cassette (ABC) Protein That Serves as a Scaffold for Iron-Sulfur Cluster Biogenesis. J. Biol. Chem. 2015, 290, 29717-29731. [CrossRef] [PubMed]

25. Yuda, E.; Tanaka, N.; Fujishiro, T.; Yokoyama, N.; Hirabayashi, K.; Fukuyama, K.; Wada, K.; Takahashi, Y. Mapping the Key Residues of SufB and SufD Essential for Biosynthesis of Iron-Sulfur Clusters. Sci. Rep. 2017, 7, 9387. [CrossRef]

26. Saini, A.; Mapolelo, D.T.; Chahal, H.K.; Johnson, M.K.; Outten, F.W. SufD and SufC ATPase Activity Are Required for Iron Acquisition during in Vivo Fe-S Cluster Formation on SufB. Biochemistry 2010, 49, 9402-9412. [CrossRef]

27. Blanc, B.; Clémancey, M.; Latour, J.-M.; Fontecave, M.; Ollagnier de Choudens, S. Molecular Investigation of Iron-Sulfur Cluster Assembly Scaffolds under Stress. Biochemistry 2014, 53, 7867-7869. [CrossRef] [PubMed]

28. Wollers, S.; Layer, G.; Garcia-Serres, R.; Signor, L.; Clemancey, M.; Latour, J.-M.; Fontecave, M.; Ollagnier de Choudens, S. Iron-Sulfur (Fe-S) Cluster Assembly: The SufBCD Complex Is a New Type of Fe-S Scaffold with a Flavin Redox Cofactor. J. Biol. Chem. 2010, 285, 23331-23341. [CrossRef]

29. Zheng, C.; Guo, S.; Tennant, W.G.; Pradhan, P.K.; Black, K.A.; Dos Santos, P.C. The Thioredoxin System Reduces Protein Persulfide Intermediates Formed during the Synthesis of Thio-Cofactors in Bacillus subtilis. Biochemistry 2019, 58, 1892-1904. [CrossRef]

30. Parent, A.; Elduque, X.; Cornu, D.; Belot, L.; Le Caer, J.-P.; Grandas, A.; Toledano, M.B.; D'Autréaux, B. Mammalian Frataxin Directly Enhances Sulfur Transfer of NFS1 Persulfide to Both ISCU and Free Thiols. Nat. Commun. 2015, 6, 5686. [CrossRef]

31. Gervason, S.; Larkem, D.; Mansour, A.B.; Botzanowski, T.; Müller, C.S.; Pecqueur, L.; Le Pavec, G.; Delaunay-Moisan, A.; Brun, O.; Agramunt, J.; et al. Physiologically Relevant Reconstitution of Iron-Sulfur Cluster Biosynthesis Uncovers Persulfide-Processing Functions of Ferredoxin-2 and Frataxin. Nat. Commun. 2019, 10, 3566. [CrossRef] [PubMed] 
32. Blauenburg, B.; Mielcarek, A.; Altegoer, F.; Fage, C.D.; Linne, U.; Bange, G.; Marahiel, M.A. Crystal Structure of Bacillus subtilis Cysteine Desulfurase SufS and Its Dynamic Interaction with Frataxin and Scaffold Protein SufU. PLoS ONE 2016, 11, e0158749. [CrossRef]

33. Turowski, V.R.; Aknin, C.; Maliandi, M.V.; Buchensky, C.; Leaden, L.; Peralta, D.A.; Busi, M.V.; Araya, A.; Gomez-Casati, D.F. Frataxin Is Localized to Both the Chloroplast and Mitochondrion and Is Involved in Chloroplast Fe-S Protein Function in Arabidopsis. PLoS ONE 2015, 10, e0141443. [CrossRef] [PubMed]

34. Roret, T.; Tsan, P.; Couturier, J.; Zhang, B.; Johnson, M.K.; Rouhier, N.; Didierjean, C. Structural and Spectroscopic Insights into Bola-Glutaredoxin Complexes. J. Biol. Chem. 2014, 289, 24588-24598. [CrossRef]

35. Vinella, D.; Brochier-Armanet, C.; Loiseau, L.; Talla, E.; Barras, F. Iron-Sulfur (Fe/S) Protein Biogenesis: Phylogenomic and Genetic Studies of A-Type Carriers. PLoS Genet. 2009, 5, e1000497. [CrossRef] [PubMed]

36. Py, B.; Gerez, C.; Angelini, S.; Planel, R.; Vinella, D.; Loiseau, L.; Talla, E.; Brochier-Armanet, C.; Garcia Serres, R.; Latour, J.-M.; et al. Molecular Organization, Biochemical Function, Cellular Role and Evolution of NfuA, an Atypical Fe-S Carrier. Mol. Microbiol. 2012, 86, 155-171. [CrossRef] [PubMed]

37. Lezhneva, L.; Amann, K.; Meurer, J. The Universally Conserved HCF101 Protein Is Involved in Assembly of [4Fe-4S]-ClusterContaining Complexes in Arabidopsis thaliana Chloroplasts. Plant J. 2004, 37, 174-185. [CrossRef]

38. Abdel-Ghany, S.E.; Ye, H.; Garifullina, G.F.; Zhang, L.; Pilon-Smits, E.A.H.; Pilon, M. Iron-Sulfur Cluster Biogenesis in Chloroplasts. Involvement of the Scaffold Protein Cpisca. Plant Physiol. 2005, 138, 161-172. [CrossRef] [PubMed]

39. Rey, P.; Becuwe, N.; Tourrette, S.; Rouhier, N. Involvement of Arabidopsis Glutaredoxin S14 in the Maintenance of Chlorophyll Content. Plant Cell Environ. 2017, 40, 2319-2332. [CrossRef]

40. Touraine, B.; Vignols, F.; Przybyla-Toscano, J.; Ischebeck, T.; Dhalleine, T.; Wu, H.-C.; Magno, C.; Berger, N.; Couturier, J.; Dubos, C.; et al. Iron-Sulfur Protein NFU2 Is Required for Branched-Chain Amino Acid Synthesis in Arabidopsis Roots. J. Exp. Bot. 2019, 70, 1875-1889. [CrossRef]

41. Berger, N.; Vignols, F.; Przybyla-Toscano, J.; Roland, M.; Rofidal, V.; Touraine, B.; Zienkiewicz, K.; Couturier, J.; Feussner, I.; Santoni, V.; et al. Identification of Client Iron-Sulfur Proteins of the Chloroplastic NFU2 Transfer Protein in Arabidopsis thaliana. J. Exp. Bot. 2020. [CrossRef] [PubMed]

42. Berger, N.; Vignols, F.; Touraine, B.; Taupin-Broggini, M.; Rofidal, V.; Demolombe, V.; Santoni, V.; Rouhier, N.; Gaymard, F.; Dubos, C. A Global Proteomic Approach Sheds New Light on Potential Iron-Sulfur Client Proteins of the Chloroplastic Maturation Factor NFU3. Int. J. Mol. Sci. 2020, 21, 8121. [CrossRef]

43. Gao, H.; Subramanian, S.; Couturier, J.; Naik, S.G.; Kim, S.-K.; Leustek, T.; Knaff, D.B.; Wu, H.-C.; Vignols, F.; Huynh, B.H.; et al Arabidopsis thaliana Nfu2 Accommodates [2Fe-2S] or [4Fe-4S] Clusters and Is Competent for in Vitro Maturation of Chloroplast [2Fe-2S] and [4Fe-4S] Cluster-Containing Proteins. Biochemistry 2013, 52, 6633-6645. [CrossRef] [PubMed]

44. Gao, H.; Azam, T.; Randeniya, S.; Couturier, J.; Rouhier, N.; Johnson, M.K. Function and Maturation of the Fe-S Center in Dihydroxyacid Dehydratase from Arabidopsis. J. Biol. Chem. 2018, 293, 4422-4433. [CrossRef]

45. Wang, L.; Ouyang, B.; Li, Y.; Feng, Y.; Jacquot, J.-P.; Rouhier, N.; Xia, B. Glutathione Regulates the Transfer of Iron-Sulfur Cluster from Monothiol and Dithiol Glutaredoxins to Apo Ferredoxin. Protein Cell 2012, 3, 714-721. [CrossRef]

46. Bandyopadhyay, S.; Gama, F.; Molina-Navarro, M.M.; Gualberto, J.M.; Claxton, R.; Naik, S.G.; Huynh, B.H.; Herrero, E.; Jacquot, J.P.; Johnson, M.K.; et al. Chloroplast Monothiol Glutaredoxins as Scaffold Proteins for the Assembly and Delivery of [2Fe-2S] Clusters. EMBO J. 2008, 27, 1122-1133. [CrossRef]

47. Mapolelo, D.T.; Zhang, B.; Randeniya, S.; Albetel, A.-N.; Li, H.; Couturier, J.; Outten, C.E.; Rouhier, N.; Johnson, M.K. Monothiol Glutaredoxins and A-Type Proteins: Partners in Fe-S Cluster Trafficking. Dalton Trans. 2013, 42, 3107-3115. [CrossRef]

48. Keeling, P.J.; Burki, F. Progress towards the Tree of Eukaryotes. Curr. Biol. 2019, 29, R808-R817. [CrossRef]

49. Grigoriev, I.V.; Hayes, R.D.; Calhoun, S.; Kamel, B.; Wang, A.; Ahrendt, S.; Dusheyko, S.; Nikitin, R.; Mondo, S.J.; Salamov, A.; et al. PhycoCosm, a Comparative Algal Genomics Resource. Nucleic Acids Res. 2020. [CrossRef]

50. Janouškovec, J.; Horák, A.; Oborník, M.; Lukeš, J.; Keeling, P.J. A Common Red Algal Origin of the Apicomplexan, Dinoflagellate, and Heterokont Plastids. Proc. Natl. Acad. Sci. USA 2010, 107, 10949-10954. [CrossRef] [PubMed]

51. Godman, J.; Balk, J. Genome Analysis of Chlamydomonas reinhardtii Reveals the Existence of Multiple, Compartmentalized Iron-Sulfur Protein Assembly Machineries of Different Evolutionary Origins. Genetics 2008, 179, 59-68. [CrossRef]

52. Terashima, M.; Specht, M.; Naumann, B.; Hippler, M. Characterizing the Anaerobic Response of Chlamydomonas reinhardtii by Quantitative Proteomics. Mol. Cell. Proteom. 2010, 9, 1514-1532. [CrossRef] [PubMed]

53. Murthy, N.U.; Ollagnier-de-Choudens, S.; Sanakis, Y.; Abdel-Ghany, S.E.; Rousset, C.; Ye, H.; Fontecave, M.; Pilon-Smits, E.A.H.; Pilon, M. Characterization of Arabidopsis thaliana SufE2 and SufE3: Functions in Chloroplast Iron-Sulfur Cluster Assembly and Nad Synthesis. J. Biol. Chem. 2007, 282, 18254-18264. [CrossRef]

54. Couturier, J.; Jacquot, J.-P.; Rouhier, N. Evolution and Diversity of Glutaredoxins in Photosynthetic Organisms. Cell. Mol. Life Sci. 2009, 66, 2539-2557. [CrossRef]

55. Waller, J.C.; Ellens, K.W.; Alvarez, S.; Loizeau, K.; Ravanel, S.; Hanson, A.D. Mitochondrial and Plastidial COG0354 Proteins Have Folate-Dependent Functions in Iron-Sulphur Cluster Metabolism. J. Exp. Bot. 2012, 63, 403-411. [CrossRef]

56. Yang, W.; Wittkopp, T.M.; Li, X.; Warakanont, J.; Dubini, A.; Catalanotti, C.; Kim, R.G.; Nowack, E.C.M.; Mackinder, L.C.M.; Aksoy, M.; et al. Critical Role of Chlamydomonas reinhardtii Ferredoxin-5 in Maintaining Membrane Structure and Dark Metabolism. Proc. Natl. Acad. Sci. USA 2015, 112, 14978-14983. [CrossRef] [PubMed] 
57. Sawyer, A.; Winkler, M. Evolution of Chlamydomonas reinhardtii Ferredoxins and Their Interactions with [FeFe]-Hydrogenases. Photosynth. Res. 2017, 134, 307-316. [CrossRef] [PubMed]

58. Goh, F.Q.Y.; Jeyakani, J.; Tipthara, P.; Cazenave-Gassiot, A.; Ghosh, R.; Bogard, N.; Yeo, Z.; Wong, G.K.S.; Melkonian, M.; Wenk, M.R.; et al. Gains and Losses of Metabolic Function Inferred from a Phylotranscriptomic Analysis of Algae. Sci. Rep. 2019, 9, 10482. [CrossRef] [PubMed]

59. Lichtenthaler, H.K. The 1-Deoxy-d-Xylulose-5-Phosphate Pathway of Isoprenoid Biosynthesis in Plants. Annu. Rev. Plant Biol. 1999, 50, 47-65. [CrossRef] [PubMed]

60. Lohr, M.; Schwender, J.; Polle, J.E.W. Isoprenoid Biosynthesis in Eukaryotic Phototrophs: A Spotlight on Algae. Plant Sci. 2012, 186, 9-22. [CrossRef]

61. Athanasakoglou, A.; Kampranis, S.C. Diatom Isoprenoids: Advances and Biotechnological Potential. Biotechnol. Adv. 2019, 37, 107417. [CrossRef]

62. Ebenezer, T.E.; Zoltner, M.; Burrell, A.; Nenarokova, A.; Novák Vanclová, A.M.G.; Prasad, B.; Soukal, P.; Santana-Molina, C.; O'Neill, E.; Nankissoor, N.N.; et al. Transcriptome, Proteome and Draft Genome of Euglena gracilis. BMC Biol. 2019, 17, 11. [CrossRef]

63. Lu, Y.; Zhou, W.; Wei, L.; Li, J.; Jia, J.; Li, F.; Smith, S.M.; Xu, J. Regulation of the Cholesterol Biosynthetic Pathway and Its Integration with Fatty Acid Biosynthesis in the Oleaginous Microalga Nannochloropsis oceanica. Biotechnol. Biofuels $2014,7,81$. [CrossRef] [PubMed]

64. Bentlage, B.; Rogers, T.S.; Bachvaroff, T.R.; Delwiche, C.F. Complex Ancestries of Isoprenoid Synthesis in Dinoflagellates. J. Eukaryot. Microbiol. 2016, 63, 123-137. [CrossRef]

65. Schoefs, B.; Franck, F. Protochlorophyllide Reduction: Mechanisms and Evolution. Photochem. Photobiol. 2003, $78,543-557$. [CrossRef]

66. Schneidewind, J.; Krause, F.; Bocola, M.; Stadler, A.M.; Davari, M.D.; Schwaneberg, U.; Jaeger, K.E.; Krauss, U. Consensus Model of a Cyanobacterial Light-Dependent Protochlorophyllide Oxidoreductase in Its Pigment-Free Apo-Form and Photoactive Ternary Complex. Commun. Biol. 2019, 2, 351. [CrossRef]

67. Moser, J.; Lange, C.; Krausze, J.; Rebelein, J.; Schubert, W.-D.; Ribbe, M.W.; Heinz, D.W.; Jahn, D. Structure of ADP-Aluminium Fluoride-Stabilized Protochlorophyllide Oxidoreductase Complex. Proc. Natl. Acad. Sci. USA 2013, 110, 2094-2098. [CrossRef]

68. Vedalankar, P.; Tripathy, B.C. Evolution of Light-Independent Protochlorophyllide Oxidoreductase. Protoplasma 2019, $256,293-312$. [CrossRef] [PubMed]

69. Cheng, Q.; Day, A.; Dowson-Day, M.; Shen, G.F.; Dixon, R. The Klebsiella pneumoniae Nitrogenase Fe Protein Gene (NifH) Functionally Substitutes for the ChlL Gene in Chlamydomonas reinhardtii. Biochem. Biophys. Res. Commun. 2005, 329, 966-975. [CrossRef]

70. Li, J.; Goldschmidt-Clermont, M.; Timko, M.P. Chloroplast-Encoded ChlB Is Required for Light-Independent Protochlorophyllide Reductase Activity in Chlamydomonas reinhardtii. Plant Cell 1993, 5, 1817-1829. [CrossRef]

71. Cahoon, A.B.; Timko, M.P. Yellow-in-the-Dark Mutants of Chlamydomonas Lack the CHLL Subunit of Light-Independent Protochlorophyllide Reductase. Plant Cell 2000, 12, 559-568. [CrossRef] [PubMed]

72. Jain, K.; Krause, K.; Grewe, F.; Nelson, G.F.; Weber, A.P.M.; Christensen, A.C.; Mower, J.P. Extreme Features of the Galdieria sulphuraria Organellar Genomes: A Consequence of Polyextremophily. Genome Biol. Evol. 2014, 7, 367-380. [CrossRef] [PubMed]

73. Ohta, N.; Matsuzaki, M.; Misumi, O.; Miyagishima, S.-y.; Nozaki, H.; Tanaka, K.; Shin-I, T.; Kohara, Y.; Kuroiwa, T. Complete Sequence and Analysis of the Plastid Genome of the Unicellular Red Alga Cyanidioschyzon merolae. DNA Res. 2003, 10, 67-77. [CrossRef] [PubMed]

74. Reith, M.; Munholland, J. Complete Nucleotide Sequence of the Porphyra purpurea Chloroplast Genome. Plant Mol. Biol. Rep. 1995, 13, 333-335. [CrossRef]

75. Robbens, S.; Derelle, E.; Ferraz, C.; Wuyts, J.; Moreau, H.; Van De Peer, Y. The Complete Chloroplast and Mitochondrial DNA Sequence of Ostreococcus tauri: Organelle Genomes of the Smallest Eukaryote Are Examples of Compaction. Mol. Biol. Evol. 2007, 24, 956-968. [CrossRef] [PubMed]

76. Lemieux, C.; Otis, C.; Turmel, M. Six Newly Sequenced Chloroplast Genomes from Prasinophyte Green Algae Provide Insights into the Relationships among Prasinophyte Lineages and the Diversity of Streamlined Genome Architecture in Picoplanktonic Species. BMC Genom. 2014, 15, 857. [CrossRef]

77. Gallaher, S.D.; Fitz-Gibbon, S.T.; Strenkert, D.; Purvine, S.O.; Pellegrini, M.; Merchant, S.S. High-Throughput Sequencing of the Chloroplast and Mitochondrion of Chlamydomonas reinhardtii to Generate Improved de Novo Assemblies, Analyze Expression Patterns and Transcript Speciation, and Evaluate Diversity among Laboratory Strains and Wild Isolates. Plant J. 2018, 93, 545-565. [CrossRef]

78. Wakasugi, T.; Nagai, T.; Kapoor, M.; Sugita, M.; Ito, M.; Ito, S.; Tsudzuki, J.; Nakashima, K.; Tsudzuki, T.; Suzuki, Y.; et al Complete Nucleotide Sequence of the Chloroplast Genome from the Green Alga Chlorella vulgaris: The Existence of Genes Possibly Involved in Chloroplast Division. Proc. Natl. Acad. Sci. USA 1997, 94, 5967-5972. [CrossRef] [PubMed]

79. Civan, P.; Foster, P.G.; Embley, M.T.; Séneca, A.; Cox, C.J. Analyses of Charophyte Chloroplast Genomes Help Characterize The ancestral Chloroplast genome of Land Plants. Genome Biol. Evol. 2014, 6, 897-911. [CrossRef]

80. Turmel, M.; Otis, C.; Lemieux, C. The Chloroplast Genome Sequence of Chara vulgaris Sheds New Light into the Closest Green Algal Relatives of Land Plants. Mol. Biol. Evol. 2006, 23, 1324-1338. [CrossRef] 
81. Oudot-Le Secq, M.P.; Grimwood, J.; Shapiro, H.; Armbrust, E.V.; Bowler, C.; Green, B.R. Chloroplast Genomes of the Diatoms Phaeodactylum tricornutum and Thalassiosira pseudonana: Comparison with Other Plastid Genomes of the Red Lineage. Mol. Genet. Genom. 2007, 277, 427-439. [CrossRef] [PubMed]

82. Wei, L.; Xin, Y.; Wang, D.; Jing, X.; Zhou, Q.; Su, X.; Jia, J.; Ning, K.; Chen, F.; Hu, Q.; et al. Nannochloropsis Plastid and Mitochondrial Phylogenomes Reveal Organelle Diversification Mechanism and Intragenus Phylotyping Strategy in Microalgae. BMC Genom. 2013, 14, 534. [CrossRef] [PubMed]

83. Barbrook, A.C.; Voolstra, C.R.; Howe, C.J. The Chloroplast Genome of a Symbiodinium Sp. Clade C3 Isolate. Protist 2014, 165, 1-13. [CrossRef]

84. Rogers, M.B.; Gilson, P.R.; Su, V.; McFadden, G.I.; Keeling, P.J. The Complete Chloroplast Genome of the Chlorarachniophyte Bigelowiella natans: Evidence for Independent Origins of Chlorarachniophyte and Euglenid Secondary Endosymbionts. Mol. Biol. Evol. 2007, 24, 54-62. [CrossRef]

85. Tanifuji, G.; Onodera, N.T.; Brown, M.W.; Curtis, B.A.; Roger, A.J.; Ka-Shu Wong, G.; Melkonian, M.; Archibald, J.M. Nucleomorph and Plastid Genome Sequences of the Chlorarachniophyte Lotharella oceanica: Convergent Reductive Evolution and Frequent Recombination in Nucleomorph-Bearing Algae. BMC Genom. 2014, 15, 374. [CrossRef] [PubMed]

86. Sanchez Puerta, V.; Bachvaroff, T.R.; Delwiche, C.F. The Complete Plastid Genome Sequence of the Haptophyte Emiliania huxleyi: A Comparison to Other Plastid Genomes. DNA Res. 2005, 12, 151-156. [CrossRef]

87. Méndez-Leyva, A.B.; Guo, J.; Mudd, E.A.; Wong, J.; Schwartz, J.M.; Day, A. The Chloroplast Genome of the Marine Microalga Tisochrysis lutea. Mitochondrial DNA Part B Resour. 2019, 4, 253-255. [CrossRef]

88. Tang, X.; Bi, G. The Complete Chloroplast Genome of Guillardia theta Strain CCMP2712. Mitochondrial DNA Part DNA Mapp. Seq. Anal. 2016, 27, 4423-4424. [CrossRef]

89. Khan, H.; Parks, N.; Kozera, C.; Curtis, B.A.; Parsons, B.J.; Bowman, S.; Archibald, J.M. Plastid Genome Sequence of the Cryptophyte Alga Rhodomonas salina CCMP1319: Lateral Transfer of Putative DNA Replication Machinery and a Test of Chromist Plastid Phylogeny. Mol. Biol. Evol. 2007, 24, 1832-1842. [CrossRef]

90. Kim, J.I.; Moore, C.E.; Archibald, J.M.; Bhattacharya, D.; Yi, G.; Yoon, H.S.; Shin, W. Evolutionary Dynamics of Cryptophyte Plastid Genomes. Genome Biol. Evol. 2017, 9, 1859-1872. [CrossRef]

91. Hallick, R.B.; Hong, L.; Drager, R.G.; Favreau, M.R.; Monfort, A.; Orsat, B.; Spielmann, A.; Stutz, E. Complete Sequence of Euglena gracilis Chloroplast DNA. Nucleic Acids Res. 1993, 21, 3537-3544. [CrossRef]

92. Dabbagh, N.; Bennett, M.S.; Triemer, R.E.; Preisfeld, A. Chloroplast Genome Expansion by Intron Multiplication in the Basal Psychrophilic Euglenoid Eutreptiella pomquetensis. PeerJ 2017, 5, e3725. [CrossRef]

93. Hunsperger, H.M.; Randhawa, T.; Cattolico, R.A. Extensive Horizontal Gene Transfer, Duplication, and Loss of Chlorophyll Synthesis Genes in the Algae. BMC Evol. Biol. 2015, 15, 16. [CrossRef] [PubMed]

94. Cvetkovska, M.; Orgnero, S.; Hüner, N.P.A.; Smith, D.R. The Enigmatic Loss of Light-Independent Chlorophyll Biosynthesis from an Antarctic Green Alga in a Light-Limited Environment. New Phytol. 2019, 222, 651-656. [CrossRef]

95. Peltier, G.; Aro, E.M.; Shikanai, T. NDH-1 and NDH-2 Plastoquinone Reductases in Oxygenic Photosynthesis. Annu. Rev. Plant Biol. 2016, 67, 55-80. [CrossRef]

96. Schuller, J.M.; Birrell, J.A.; Tanaka, H.; Konuma, T.; Wulfhorst, H.; Cox, N.; Schuller, S.K.; Thiemann, J.; Lubitz, W.; Sétif, P.; et al. Structural Adaptations of Photosynthetic Complex I Enable Ferredoxin-Dependent Electron Transfer. Science 2019, 363, 257-260. [CrossRef]

97. Martín, M.; Sabater, B. Plastid Ndh Genes in Plant Evolution. Plant Physiol. Biochem. 2010, 48, 636-645. [CrossRef] [PubMed]

98. Jans, F.; Mignolet, E.; Houyoux, P.A.; Cardol, P.; Ghysels, B.; Cuiné, S.; Cournac, L.; Peltier, G.; Remacle, C.; Franck, F. A Type Ii $\mathrm{Nad}(\mathrm{p}) \mathrm{h}$ Dehydrogenase Mediates Light-Independent Plastoquinone Reduction in the Chloroplast of Chlamydomonas. Proc. Natl. Acad. Sci. USA 2008, 105, 20546-20551. [CrossRef]

99. Desplats, C.; Mus, F.; Cuiné, S.; Billon, E.; Cournac, L.; Peltier, G. Characterization of Nda2, a Plastoquinone-Reducing Type II NAD (P) H Dehydrogenase in Chlamydomonas Chloroplasts. J. Biol. Chem. 2009, 284, 4148-4157. [CrossRef] [PubMed]

100. Saroussi, S.; Sanz-Luque, E.; Kim, R.G.; Grossman, A.R. Nutrient Scavenging and Energy Management: Acclimation Responses in Nitrogen and Sulfur Deprived Chlamydomonas. Curr. Opin. Plant Biol. 2017, 39, 114-122. [CrossRef] [PubMed]

101. Baltz, A.; Dang, K.V.; Beyly, A.; Auroy, P.; Richaud, P.; Cournac, L.; Peltier, G. Plastidial Expression of Type II NAD(P)H Dehydrogenase Increases the Reducing State of Plastoquinones and Hydrogen Photoproduction Rate by the Indirect Pathway in Chlamydomonas reinhardtii. Plant Physiol. 2014, 165, 1344-1352. [CrossRef] [PubMed]

102. Grossman, A.; Sanz-Luque, E.; Yi, H.; Yang, W. Building the Greencut2 Suite of Proteins to Unmask Photosynthetic Function and Regulation. Microbiology 2019, 165, 697-718. [CrossRef]

103. Fristedt, R.; Herdean, A.; Blaby-Haas, C.E.; Mamedov, F.; Merchant, S.S.; Last, R.L.; Lundin, B. PHOTOSYSTEM II PROTEIN33, a Protein Conserved in the Plastid Lineage, Is Associated with the Chloroplast Thylakoid Membrane and Provides Stability to Photosystem II Supercomplexes in Arabidopsis. Plant Physiol. 2015, 167, 481-492. [CrossRef]

104. Kato, Y.; Yokono, M.; Akimoto, S.; Takabayashi, A.; Tanaka, A.; Tanaka, R. Deficiency of the Stroma-Lamellar Protein LIL8/PSB33 Affects Energy Transfer Around PSI in Arabidopsis. Plant Cell Physiol. 2017, 58, 2026-2039. [CrossRef] [PubMed]

105. Urzica, E.I.; Casero, D.; Yamasaki, H.; Hsieh, S.I.; Adler, L.N.; Karpowicz, S.J.; Blaby-Haas, C.E.; Clarke, S.G.; Loo, J.A.; Pellegrini, M.; et al. Systems and Trans-System Level Analysis Identifies Conserved Iron Deficiency Responses in the Plant Lineage. Plant Cell 2012, 24, 3921-3948. [CrossRef] [PubMed] 
106. Ibrahim, I.M.; Wu, H.; Ezhov, R.; Kayanja, G.E.; Zakharov, S.D.; Du, Y.; Tao, W.A.; Pushkar, Y.; Cramer, W.A.; Puthiyaveetil, S. An Evolutionarily Conserved Iron-Sulfur Cluster Underlies Redox Sensory Function of the Chloroplast Sensor Kinase. Commun. Biol. 2020, 3, 13. [CrossRef] [PubMed]

107. Harris, E.H. The Chlamydomonas Sourcebook; Elsevier Academic Press Inc.: New York, NY, USA, 1989; ISBN 978-0-12-326880-8.

108. Atteia, A.; Van Lis, R.; Tielens, A.G.M.; Martin, W.F. Anaerobic Energy Metabolism in Unicellular Photosynthetic Eukaryotes. Biochim. Biophys. Acta Bioenerg. 2013, 1827, 210-223. [CrossRef] [PubMed]

109. Catalanotti, C.; Yang, W.; Posewitz, M.C.; Grossman, A.R. Fermentation Metabolism and Its Evolution in Algae. Front. Plant Sci. 2013, 4, 150. [CrossRef]

110. Yang, W.; Catalanotti, C.; Wittkopp, T.M.; Posewitz, M.C.; Grossman, A.R. Algae after Dark: Mechanisms to Cope with Anoxic/Hypoxic Conditions. Plant J. 2015, 82, 481-503. [CrossRef]

111. Olson, A.C.; Carter, C.J. The Involvement of Hybrid Cluster Protein 4, HCP4, in Anaerobic Metabolism in Chlamydomonas reinhardtii. PLoS ONE 2016, 11, e0149816. [CrossRef]

112. Atteia, A.; van Lis, R.; Gelius-Dietrich, G.; Adrait, A.; Garin, J.; Joyard, J.; Rolland, N.; Martin, W. Pyruvate Formate-Lyase and a Novel Route of Eukaryotic ATP Synthesis in Chlamydomonas Mitochondria. J. Biol. Chem. 2006, 281, 9909-9918. [CrossRef]

113. Broderick, J.B.; Henshaw, T.F.; Cheek, J.; Wojtuszewski, K.; Smith, S.R.; Trojan, M.R.; McGhan, R.M.; Kopf, A.; Kibbey, M.; Broderick, W.E. Pyruvate Formate-Lyase-Activating Enzyme: Strictly Anaerobic Isolation Yields Active Enzyme Containing a [3Fe-4S]+ Cluster. Biochem. Biophys. Res. Commun. 2000, 269, 451-456. [CrossRef]

114. Shisler, K.A.; Hutcheson, R.U.; Horitani, M.; Duschene, K.S.; Crain, A.V.; Byer, A.S.; Shepard, E.M.; Rasmussen, A.; Yang, J.; Broderick, W.E.; et al. Monovalent Cation Activation of the Radical SAM Enzyme Pyruvate Formate-Lyase Activating Enzyme. J. Am. Chem. Soc. 2017, 139, 11803-11813. [CrossRef]

115. Wagner, A.F.V.; Frey, M.; Neugebauer, F.A.; Schafer, W.; Knappe, J. The Free Radical in Pyruvate Formate-Lyase Is Located on Glycine-734. Proc. Natl. Acad. Sci. USA 1992, 89, 996-1000. [CrossRef] [PubMed]

116. Catalanotti, C.; Dubini, A.; Subramanian, V.; Yang, W.; Magneschi, L.; Mus, F.; Seibert, M.; Posewitz, M.C.; Grossman, A.R. Altered Fermentative Metabolism in Chlamydomonas reinhardtii Mutants Lacking Pyruvate Formate Lyase and Both Pyruvate Formate Lyase and Alcohol Dehydrogenase. Plant Cell 2012, 24, 692-707. [CrossRef]

117. Van Lis, R.; Baffert, C.; Couté, Y.; Nitschke, W.; Atteia, A. Chlamydomonas reinhardtii Chloroplasts Contain a Homodimeric Pyruvate:Ferredoxin Oxidoreductase That Functions with FDX1. Plant Physiol. 2013, 161, 57-71. [CrossRef] [PubMed]

118. Noth, J.; Krawietz, D.; Hemschemeier, A.; Happe, T. Pyruvate:Ferredoxin Oxidoreductase Is Coupled to Light-Independent Hydrogen Production in Chlamydomonas reinhardtii. J. Biol. Chem. 2013, 288, 4368-4377. [CrossRef] [PubMed]

119. Fukuda, E.; Kino, H.; Matsuzawa, H.; Wakagi, T. Role of a Highly Conserved YPITP Motif in 2-Oxoacid:Ferredoxin Oxidoreductase. Eur. J. Biochem. 2001, 268, 5639-5646. [CrossRef]

120. Meuser, J.E.; D’Adamo, S.; Jinkerson, R.E.; Mus, F.; Yang, W.; Ghirardi, M.L.; Seibert, M.; Grossman, A.R.; Posewitz, M.C. Genetic Disruption of Both Chlamydomonas reinhardtii [FeFe]-Hydrogenases: Insight into the Role of HYDA2 in H2 Production. Biochem. Biophys. Res. Commun. 2012, 417, 704-709. [CrossRef]

121. Mulder, D.W.; Boyd, E.S.; Sarma, R.; Lange, R.K.; Endrizzi, J.A.; Broderick, J.B.; Peters, J.W. Stepwise FeFe-Hydrogenase H-Cluster Assembly Revealed in the Structure of HydA $\triangle \mathrm{eFG}$. Nature 2010, 465, 248-252. [CrossRef]

122. Peters, J.W. X-Ray Crystal Structure of the Fe-Only Hydrogenase (CpI) from Clostridium pasteurianum to 1.8 Angstrom Resolution Science 1998, 282, 1853-1858. [CrossRef]

123. Esselborn, J.; Muraki, N.; Klein, K.; Engelbrecht, V.; Metzler-Nolte, N.; Apfel, U.P.; Hofmann, E.; Kurisu, G.; Happe, T. A Structural View of Synthetic Cofactor Integration into [Fefe]-Hydrogenases. Chem. Sci. 2016, 7, 959-968. [CrossRef]

124. Byer, A.S.; Shepard, E.M.; Ratzloff, M.W.; Betz, J.N.; King, P.W.; Broderick, W.E.; Broderick, J.B. H-Cluster Assembly Intermediates Built on HydF by the Radical SAM Enzymes HydE and HydG. J. Biol. Inorg. Chem. 2019, 24, 783-792. [CrossRef] [PubMed]

125. Sawyer, A.; Bai, Y.; Lu, Y.; Hemschemeier, A.; Happe, T. Compartmentalisation of [FeFe]-Hydrogenase Maturation in Chlamydomonas reinhardtii. Plant J. 2017, 90, 1134-1143. [CrossRef]

126. Posewitz, M.C.; King, P.W.; Smolinski, S.L.; Zhang, L.; Seibert, M.; Ghirardi, M.L. Discovery of Two Novel Radical SAdenosylmethionine Proteins Required for the Assembly of an Active [Fe] Hydrogenase. J. Biol. Chem. 2004, 279, 25711-25720. [CrossRef] [PubMed]

127. King, P.W.; Posewitz, M.C.; Ghirardi, M.L.; Seibert, M. Functional Studies of [FeFe] Hydrogenase Maturation in an Escherichia coli Biosynthetic System. J. Bacteriol. 2006, 188, 2163-2172. [CrossRef]

128. D'Adamo, S.; Jinkerson, R.E.; Boyd, E.S.; Brown, S.L.; Baxter, B.K.; Peters, J.W.; Posewitz, M.C. Evolutionary and Biotechnological Implications of Robust Hydrogenase Activity in Halophilic Strains of Tetraselmis. PLoS ONE 2014, 9, e85812. [CrossRef]

129. Vieler, A.; Wu, G.; Tsai, C.H.; Bullard, B.; Cornish, A.J.; Harvey, C.; Reca, I.B.; Thornburg, C.; Achawanantakun, R.; Buehl, C.J.; et al. Genome, Functional Gene Annotation, and Nuclear Transformation of the Heterokont Oleaginous Alga Nannochloropsis oceanica CCMP1779. PLoS Genet. 2012, 8, e1003064. [CrossRef] [PubMed]

130. Aragão, D.; Macedo, S.; Mitchell, E.P.; Romão, C.V.; Liu, M.Y.; Frazão, C.; Saraiva, L.M.; Xavier, A.V.; LeGall, J.; Van Dongen, W.M.A.M.; et al. Reduced Hybrid Cluster Proteins (HCP) from Desulfovibrio desulfuricans ATCC 27774 and Desulfovibrio vulgaris (Hildenborough): X-Ray Structures at High Resolution Using Synchrotron Radiation. J. Biol. Inorg. Chem. 2003, 8, 540-548. [CrossRef] [PubMed] 
131. Cooper, S.J.; Garner, C.D.; Hagen, W.R.; Lindley, P.F.; Bailey, S. Hybrid-Cluster Protein (HCP) from Desulfovibrio vulgaris (Hildenborough) at 1.6 \AA Resolution. Biochemistry 2000, 39, 15044-15054. [CrossRef]

132. Arendsen, A.F.; Hadden, J.; Card, G.; McAlpine, A.S.; Bailey, S.; Zaitsev, V.; Duke, E.H.M.; Lindley, P.F.; Kröckel, M.; Trautwein, A.X.; et al. The "prismane" Protein Resolved: X-ray Structure at 1.7 $\backslash$ AA and Multiple Spectroscopy of Two Novel 4Fe Clusters. J. Biol. Inorg. Chem. 1998, 3, 81-95. [CrossRef]

133. Van Lis, R.; Brugière, S.; Baffert, C.; Couté, Y.; Nitschke, W.; Atteia, A. Hybrid Cluster Proteins in a Photosynthetic Microalga. FEBS J. 2020, 287, 721-735. [CrossRef]

134. Mus, F.; Dubini, A.; Seibert, M.; Posewitz, M.C.; Grossman, A.R. Anaerobic Acclimation in Chlamydomonas reinhardtii: Anoxic Gene Expression, Hydrogenase Induction, and Metabolic Pathways. J. Biol. Chem. 2007, 282, 25475-25486. [CrossRef]

135. Jez, J.M. Structural Biology of Plant Sulfur Metabolism: From Sulfate to Glutathione. J. Exp. Bot. 2019, 70, 4089-4103. [CrossRef]

136. McMinn, A.; Martin, A. Dark Survival in a Warming World. Proc. R. Soc. B Biol. Sci. 2013, 280, 20122909. [CrossRef]

137. Kamp, A.; De Beer, D.; Nitsch, J.L.; Lavik, G.; Stief, P. Diatoms Respire Nitrate to Survive Dark and Anoxic Conditions. Proc. Natl. Acad. Sci. USA 2011, 108, 5649-5654. [CrossRef]

138. Kamp, A.; Stief, P.; Knappe, J.; De Beer, D. Response of the Ubiquitous Pelagic Diatom Thalassiosira weissflogii to Darkness and Anoxia. PLoS ONE 2013, 8, e82605. [CrossRef]

139. Kamp, A.; Stief, P.; Bristow, L.A.; Thamdrup, B.; Glud, R.N. Intracellular Nitrate of Marine Diatoms as a Driver of Anaerobic Nitrogen Cycling in Sinking Aggregates. Front. Microbiol. 2016, 7, 1669. [CrossRef] [PubMed]

140. Kraft, B.; Strous, M.; Tegetmeyer, H.E. Microbial Nitrate Respiration-Genes, Enzymes and Environmental Distribution. J. Biotechnol. 2011, 155, 104-117. [CrossRef]

141. Gould, S.B.; Garg, S.G.; Handrich, M.; Nelson-Sathi, S.; Gruenheit, N.; Tielens, A.G.M.; Martin, W.F. Adaptation to Life on Land at High $\mathrm{O}_{2}$ via Transition from Ferredoxin-to NADH-Dependent Redox Balance. Proc. Biol. Sci. 2019, 286, 20191491. [CrossRef] 